\title{
THE EFFECT OF WHITE-TAILED DEER DENSITY ON BREEDING SONGBIRDS IN DELAWARE
}

\author{
by
}

Elizabeth Lynne Tymkiw

\begin{abstract}
A thesis submitted to the Faculty of the University of Delaware in partial fulfillment of the requirements for the degree of Master of Science in Wildlife Ecology
\end{abstract}

Summer 2010

Copyright 2010 Elizabeth Lynne Tymkiw

All Rights Reserved 


\section{THE EFFECT OF WHITE-TAILED DEER DENSITY ON BREEDING SONGBIRDS IN DELAWARE}

by

Elizabeth Lynne Tymkiw

Approved:

Jacob Bowman, Ph.D.

Professor in charge of thesis on behalf of the Advisory Committee

Approved:

Doug Tallamy, Ph.D.

Chair of the Department of Entomology and Wildlife Ecology

Approved:

Robin Morgan, Ph.D.

Dean of the College of Agriculture and Natural Resources

Approved:

Debra Hess Norris, M.S.

Vice Provost for Graduate and Professional Education 


\section{ACKNOWLEDGMENTS}

I have had such a great time at UD and it is $100 \%$ because of the people here. Professors, staff, grad students and undergrads alike; all have been wonderful. I'd particularly like to thank the Bowman Lab (including Bowman himself, of course), for all the help and good times.

Thanks also go out to Judy, Bo, Andy and Matt for reading, re-reading and watching the same old slide show over and over. And clearly, without my excellent committee (Dr. Bowman, Dr. Shriver and Dr. Johnson) I would have spent all year counting birds and wasting time and never would have written a thesis at all. So, thanks! 


\section{TABLE OF CONTENTS}

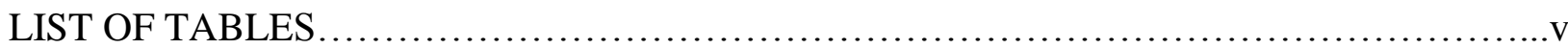

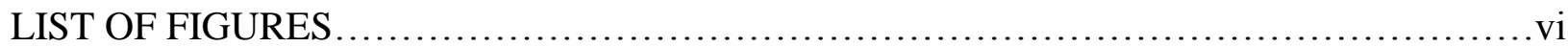

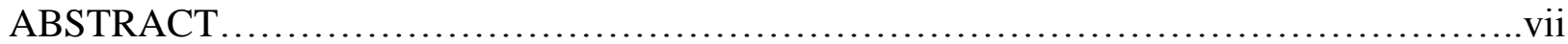

Chapter 1

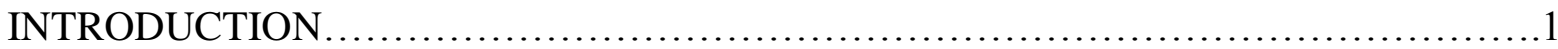

Chapter 2

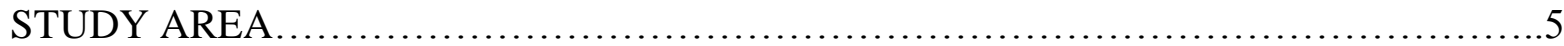

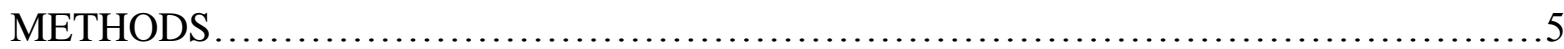

Chapter 3

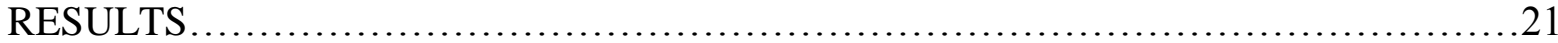

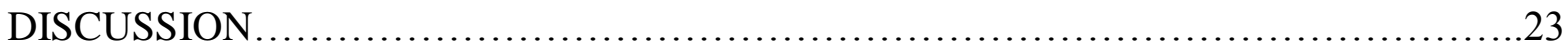

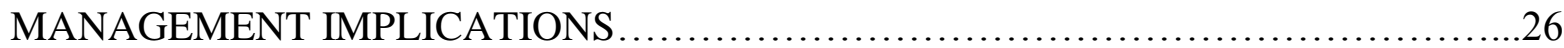

APPENDIX A

Number of detections, by species, from low, moderate and high deer densities, during point

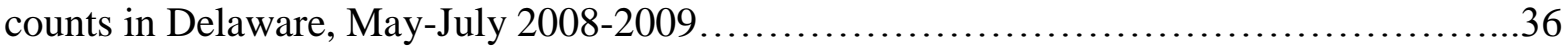

\section{APPENDIX B}

Midstory plant species (native and exotic) encountered during vegetation surveys of point count sites in Delaware, July-August 2008-2009...............................41

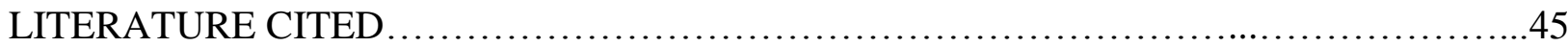




\section{LIST OF TABLES}

Table 1. Deer densities $\left(\right.$ deer $/ \mathrm{km}^{2}$ ) of the 17 deer management zones in Delaware as measured by the Delaware Division of Fish and Wildlife in 2005, 2009, an average of the 2 years. Density categories used for comparisons of avian relative abundance and species richness among deer densities...........................................................................

Table 2. Avian guilds (based on O'Connell et al. [1998] and Bishop and Meyers [2005]) and species vulnerable to high deer densities used for comparisons of avian relative abundance and species richness among deer densities categories. Species found to be sensitive to deer density in the reviewed literature are in bold ...................................................... 12

Table 3. Models used to evaluate factors affecting occupancy for species counted in Delaware, 2008-2009. $\psi$ represents occupancy covariates, $p$ represents detection covariates.............18

Table 4. A comparison of mean relative abundance and species richness of guilds counted in the Delaware Breeding Bird Survey (BBS) during 2005-2009 among low, moderate and high deer

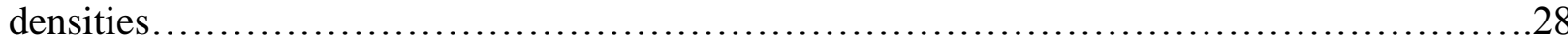

Table 5. A comparison of mean relative abundance of bird species counted in the Delaware Breeding Bird Survey (BBS) during 2005-2008 among low, moderate and high deer densities.

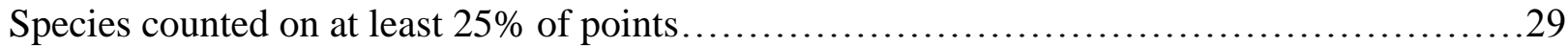

Table 6. A comparison of mean relative abundance and species richness of guilds encountered in Delaware on point counts during 2008-2009 among low, moderate and high deer densities.....30

Table 7. A comparison of mean relative abundance of birds counted in Delaware on point counts during 2008-2009 among low, moderate and high deer densities. Species counted on at least $25 \%$ of points

Table 8. Parameter estimates (B) and standard errors (SE) of occupancy models for species counted in Delaware, 2008-2009. Models are listed by $\triangle$ AIC or $\triangle$ QAIC when there was more than one well-supported model $(\triangle \mathrm{AIC}$ or $\triangle \mathrm{QAIC} \leq 2)$ for a species. Species are listed by increasing deer density $\beta$, followed by species whose occupancy was not affected by deer and

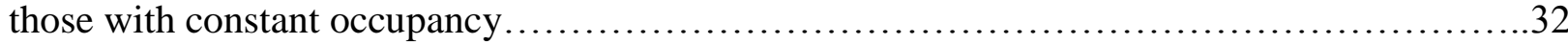

Table 9. A comparison of vegetation characteristics estimated in Delaware, 2008-2009, from low, moderate, and high deer densities .35 


\section{LIST OF FIGURES}

Figure 1. Deer densities obtained from the Delaware Division of Fish and Wildlife deer survey for each of the 17 deer management zones (average of 2005 and 2009 densities)..............4

Figure 2. Breeding Bird Survey (BBS) routes in Delaware, 2005-2008. Highlighted points have $>40 \%$ forest cover and were points used for comparisons of avian relative abundance and species richness at different deer densities. Background shading indicates deer density (light $=$

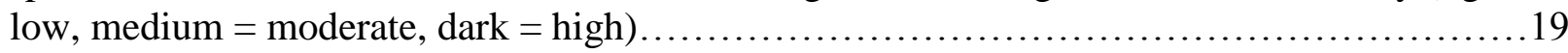

Figure 3. Location of targeted bird survey points in Delaware, 2008-2009, used for comparisons of avian relative abundance and species richness at different deer densities. Labels indicate number of points. Background shading indicates deer density (light $=$ low, medium $=$ moderate,

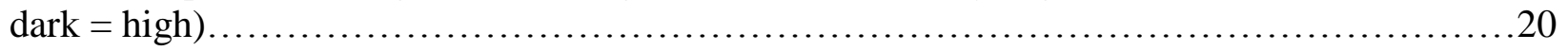




\begin{abstract}
Currently, population goals for white-tailed deer (Odocoileus virginianus) are based solely on deer data with little consideration given to other parts of the ecosystem. A wider ecological approach is needed to provide managers with a more justifiable target deer density. I investigated the use of breeding birds to determine an ecologically based carrying capacity for deer management by studying the relationship between the forest breeding bird community and deer density in Delaware. Using Breeding Bird Survey (BBS) data from 2005-2009, my own point count data from 2008-2009, and Delaware Division of Fish and Wildlife deer density data from the same time periods, I compared avian species richness and relative abundance to deer density. I divided deer densities into low $\left(\leq 10 \mathrm{deer} / \mathrm{km}^{2}\right)$, moderate $\left(11-19 \mathrm{deer} / \mathrm{km}^{2}\right)$ and high $\left(\geq 20 \mathrm{deer} / \mathrm{km}^{2}\right)$ categories. I placed birds into 7 deer-sensitive guilds: interior obligates, ground nesters, shrub nesters, ground gleaners, low canopy foragers, and neo-tropical migrants. The abundance or richness of most guilds and most individual species did not differ by deer density. Of those guilds that did, shrub nesters $(P=0.074)$, interior forest obligates $(P=0.050)$, low canopy foragers $(P<0.001)$, and neo-tropical migrants $(P=0.023)$ had the greatest species richness and/or relative abundance at low or moderate deer densities. Chipping Sparrows $(P=$ 0.021), Red-eyed Vireos $(P=0.023)$, Great Crested Flycatchers $(P=0.044)$, Acadian Flycatchers $(P<0.001)$, and Ovenbirds $(P=0.028)$ had the greatest abundances at low or moderate deer densities. Our results suggest that areas in Delaware with deer densities of $<20$ deer $/ \mathrm{km}^{2}$ have the greatest avian richness and abundance. Thus, management efforts should focus on this level as an ecological threshold that will maintain the quality of the ecosystem as a whole.
\end{abstract}




\section{Chapter 1}

\section{INTRODUCTION}

White-tailed deer (Odocoileus virginianus) abundance in North America, particularly in the Mid-Atlantic and Northeast, is well above historical levels (McCabe and McCabe 1997). Changes in the landscape to support agriculture and silviculture have improved deer habitat and game management has protected deer from overexploitation. Densities of up to $50 \mathrm{deer} / \mathrm{km}^{2}$ were recorded in Delaware in 2005 (Bowman 2006), while historically, numbers have been estimated at 3.1 - 4.2 deer $/ \mathrm{km}^{2}$ (McCabe and McCabe 1997). Hansen and Beringer (1997) recommended a density of $15 \mathrm{deer} / \mathrm{km}^{2}$ to balance the number of deer-human conflicts, damage to forest regeneration, and impacts on other species while still providing viewing and hunting opportunities. Current deer populations are a reflection of human manipulations, not the historical levels at which deer evolved (Waller and Alverson 1997).

White-tailed deer are keystone herbivores in eastern forests (Waller and Alverson 1997), meaning they can have an effect on multiple trophic levels by changing plant species composition and vegetation structure. Deer have been shown to negatively impact populations of herbaceous and woody plants, insects, and birds (Tilghman 1989, Allombert et al. 2005a, McShea and Rappole 2000). Saplings and shrubs increase in size and abundance after deer are excluded from an area (Tilghman 1989, Horsley and Marquis 1983, Harlow and Downing 1970). The groundcover is also affected, with fewer wildflowers and forbs and more ferns, grasses, and exotic species in areas with high deer densities (Gaston et al. 2006, Horsley and Marquis 1983, Eschtruth and Battles 2009). As a result of deer browsing the vegetation, less food and habitat are available for herbivorous insects. Almost all insect orders, with the exception of beetles 
(Coleoptera), are negatively affected, with some groups like the true bugs (Heteroptera), disappearing completely after 50 years in the presence of deer (Allombert et al. 2005a). Fewer insects, in turn, mean less food for insectivorous birds, which can reduce habitat quality. Also, by altering the vegetation structure deer can directly affect bird habitat and transform areas to a point where some bird species may no longer occur. The greater the deer density in an area, the stronger these effects will be.

Many forest songbirds use the understory to forage or nest and most are insectivorous at some point in their life cycle (Martin et al. 1951). McShea and Rappole (2000) found that birds which forage at low or intermediate canopy levels or undergo long migrations increased in number when deer were fenced out of forest plots. In an enclosure study of deer and several exotic ungulates, Casey and Hein (1983) found that bird species associated with the understory increased with lower ungulate density. DeCalesta (1994) found that the mean species richness of intermediate canopy nesters increased by $27 \%$ at a density of 4 deer $/ \mathrm{km}^{2}$ compared to 31 deer $/ \mathrm{km}^{2}$. Similarly, DeGraaf et al. (1991) found increased numbers of canopy gleaning species in areas with 1-3 deer $/ \mathrm{km}^{2}$ compared to areas with 13-23 deer $/ \mathrm{km}^{2}$. Allombert et al. (2005b) found that both bird abundance and species richness decreased with a longer history of deer presence on an island in British Columbia. Collectively, these studies show a connection between high deer density and low bird abundance and diversity, especially for certain sensitive guilds; however, many of these studies were conducted under unrealistic conditions. McShea and Rappole (2000) used exclosures to completely remove deer herbivory, while Casey and Hein (1983) used enclosures to maintain deer at unnaturally high densities $\left(83 / \mathrm{km}^{2}\right)$ for the area. DeCalesta (1994) also fenced deer in at unnaturally high densities $\left(25 / \mathrm{km}^{2}\right)$ for the study area and kept them in enclosures smaller than their estimated home range. These deer could have 
been forced to browse more intensely on the vegetation in the smaller area than they would in a natural setting. These studies are useful in showing differences between areas with no deer and areas with high deer densities but this situation does not often occur in nature, where a large continuum of deer densities exists.

In early December 2005 and again in the winter of 2009, the Delaware Department of Natural Resources and Environmental Control (DNREC) Division of Fish and Wildlife estimated the deer density for each of the 17 deer management zones in the state (Bernatas 2006, Bernatas 2009; Figure 1). This level of specificity provides the perfect "natural laboratory" to investigate the effects deer may be having on breeding birds at a range of deer densities. To determine the relationship deer have with forest breeding birds I used 2 data sources: 1) the Breeding Bird Survey (BBS) provided 5 years (2005-2009) of breeding bird data within the deer management zones and 2) point counts directed at forested habitat within the transects where deer density was estimated. My primary objective was to determine if deer were having an impact on breeding bird abundance and species richness. My secondary objective, if an effect was detected, was to find a threshold density for management at which deer had a minimal effect on the abundance and diversity of breeding songbirds in Delaware. 
Figure 1. Deer densities obtained from the Delaware Division of Fish and Wildlife deer survey for each of the 17 deer management zones (average of 2005 and 2009 densities).

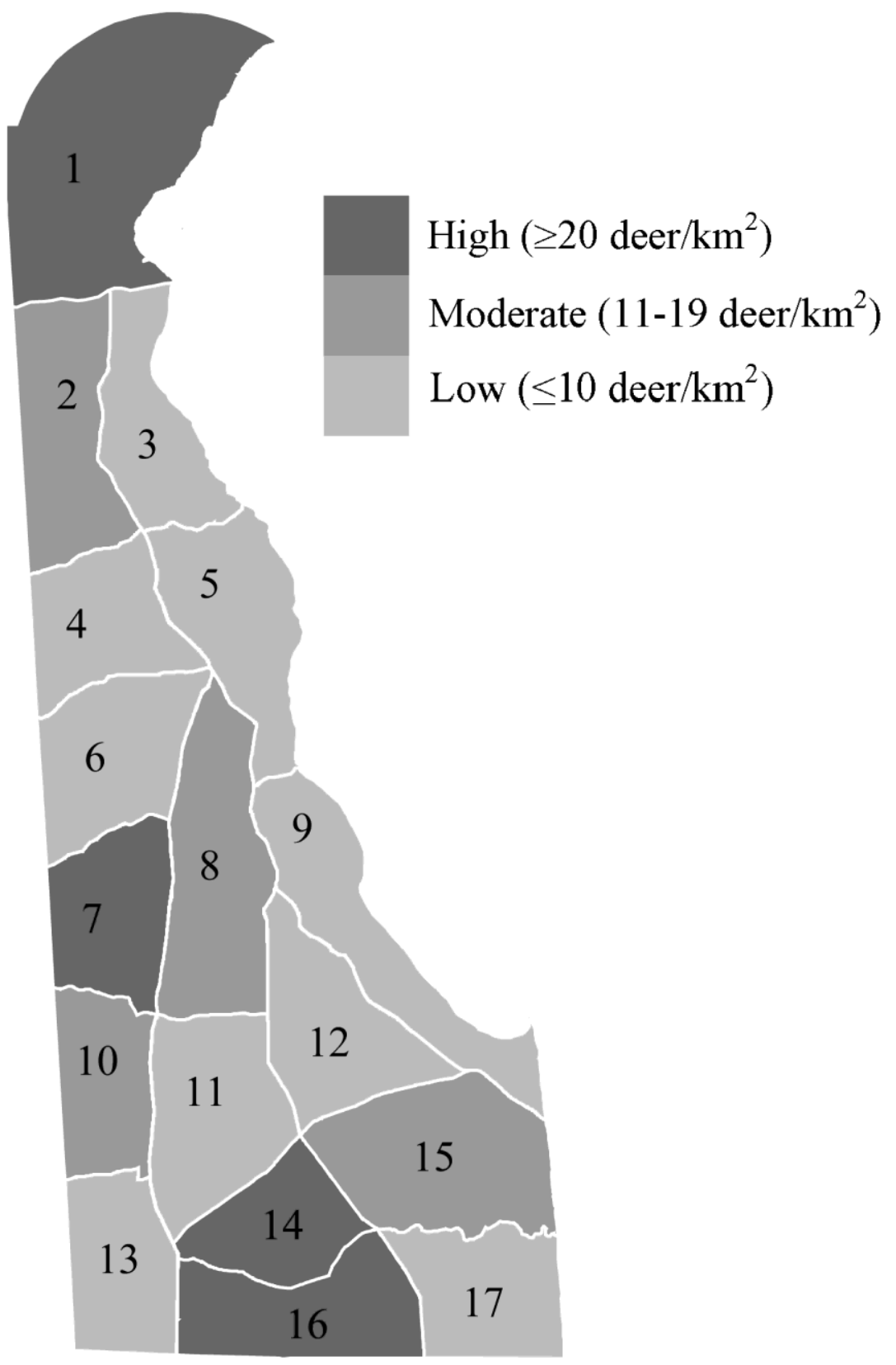




\section{Chapter 2}

\section{STUDY AREA}

Most of Delaware is on the Coastal Plain, with approximately 5\% of the state in the northwest located on the Piedmont (Hess et al. 2000). About $24 \%$ of the state was forested, of which $19 \%$ was deciduous forest, $9 \%$ was coniferous forest, $28 \%$ was mixed forest, and $44 \%$ was composed of forested wetlands. The primary forest types were oak/hickory in New Castle and Kent Counties and oak/gum/cypress and oak/pine in Sussex County (Hess et al. 2000). Common canopy species included oaks (Quercus spp.), hickories (Carya spp.), red maple (Acer rubrum), tuliptree (Liriodendron tulipifera), American beech (Fagus grandifolia), sweet gum (Liquidambar stryaciflua), black gum (Nyssa sylvatica), American sycamore (Platanus occidentalis), wild black cherry (Prunus serotina) and loblolly and Virginia pines (Pinus taeda and P. virginiana; Prasad et al. 2007). Highbush blueberry (Vaccinium corymbosum), multifloral rose (Rosa multiflora), sweet pepperbush (Clethra alnifolia), Viburnum spp., ironwood (Carpinus caroliniana), American holly (Ilex opaca), greenbrier (Smilax spp.), and blackberry (Rubus spp.) were common understory species. The average temperatures in Delaware for the past 30 years in May, June, and July were $17^{\circ} \mathrm{C}, 22^{\circ} \mathrm{C}$, and $25^{\circ} \mathrm{C}$, respectively, and the average

precipitation amounts were $11 \mathrm{~cm}, 9 \mathrm{~cm}$, and $11 \mathrm{~cm}$ (NOAA 2010). The weather during my two field seasons did not show any extreme variation from these averages.

\section{METHODS}

Deer densities were estimated using aerial surveys and Forward-Looking Infrared (FLIR) technology. In the winters of 2005 and 2009, $13.2 \mathrm{~km}$ by $12.9 \mathrm{~km}$ transect was flown in 
each of the 17 deer management zones (Bernatas 2006). Each transect was surveyed from an attitude of $305 \mathrm{~m}$. A video recorder was used to record the thermal signatures of deer. The video was reviewed after all surveys were completed. From the deer counted on these transects, a deer density was extrapolated for each zone by the Delaware Division of Fish and Wildlife. Deer densities for the 2005 season ranged from $4-45$ deer $/ \mathrm{km}^{2}$ of deer habitat, post harvest (Bowman 2006). In the winter of 2009, density estimates ranged from $2-17 \mathrm{deer} / \mathrm{km}^{2}$ of deer habitat, post harvest (J. Rogerson, Delaware Division of Fish and Wildlife, personal communication). The reduction in deer density was a result of increased harvest between the 2 survey periods. I averaged these 2 estimates for each zone to come up with a final deer density that was representative of the entire study period (Table 1). I then separated these densities into 3 categories for my analyses: low $\left(\leq 10\right.$ deer $\left./ \mathrm{km}^{2}\right)$, moderate $\left(11-19\right.$ deer $\left./ \mathrm{km}^{2}\right)$ and high $(\geq 20$ deer $/ \mathrm{km}^{2}$; Figure 1). I modeled my density categories off of DeCalesta's (1994) values. My low category consists of his lowest 2 densities, my moderate category is centered on his density of 15 deer $/ \mathrm{km}^{2}$, and my high category encompasses his highest deer density. I combined his lowest 2 densities because Delaware did not have sufficient low density zones to make separate categories.

Volunteers conducted BBS point counts (Sauer et al. 2008). During these 3-minute counts, they recorded all birds seen or heard within $400 \mathrm{~m}$ ( 0.25 miles). Observers conducted counts in early to mid-June during the first $4-5$ hours after sunrise. Because rainy or windy days can affect both bird activity and detectability, observers did not conduct surveys on these days (USGS 2007). I used BBS data from 2005-2009, during which time there were 10 active BBS routes in Delaware (Figure 2). Each route contained 50 roadside points, spaced at $800 \mathrm{~m}$ (0.5 mile) intervals. I calculated the percent forest within a $50 \mathrm{~m}$ buffer of each point using ArcView GIS 
3.2 and the 2007 USGS Land Use Land Cover data file. I considered the following land uses "forest": deciduous forest, evergreen forest, mixed forest, non-tidal forested wetlands, and tidal forested wetlands. I included points on these routes in my analyses if they contained at least $40 \%$ forest cover within the $50 \mathrm{~m}$ buffer. The BBS was designed to sample a wide variety of habitat types, so I used this cutoff to focus on the points that were actually in a forested setting.

I also conducted targeted point counts, in 2008 and 2009, in forested areas within or contiguous to the corresponding deer survey transects conducted by the Delaware Division of Fish and Wildlife (Figure 3). These points linked the avian survey results with the deer survey results. I was unable to find suitable forested areas within FLIR survey transects in zones 5 or 8 , therefore I did not establish point counts within these zones. Points were placed along minor roads with little traffic and were spaced $300 \mathrm{~m}$ apart. In 2008, I established and surveyed a total of 206 points and in 2009 I surveyed the same 206 points and added an additional route ( $\mathrm{n}=12$ points) in zone 1 to increase the sample size in high deer density areas. I visited each point 3 times from 15 May-15 July for a total of 1,272 counts. Each count was 5 minutes long, divided into 1 minute intervals. I had a 1 minute acclimation period before I began a count to let the birds adjust to my presence. During the count I recorded every bird seen or heard and placed it into 1 of 4 distance categories: 0-10 m, 10-30 m, 30-50 m and 50+ $\mathrm{m}$ (Alldredge et al. 2007). I noted flyovers separately and excluded these observations from my analyses. I started at dawn (approximately 0545) and continued for a maximum of 5 hours on suitable days between mid May and mid July. I did not conduct counts during heavy rain or fog, or wind over $11 \mathrm{~km} / \mathrm{h}$ (Ralph et al. 1995). 
To analyze the effects of deer on songbird populations, I separated species into guilds based on O'Connell et al. (1998) and Bishop and Meyers (2005). Guilds were based on primary habitat, nest placement, foraging height, and migration distance. Guilds that I expected to be sensitive to high deer densities were: interior forest obligates, shrub nesters, ground nesters, ground gleaners, low canopy foragers, and neo-tropical migrants (Table 2; Casey and Hein 1983, DeCalesta 1994, McShea and Rappole 1997, Allombert et al. 2005b, Baiser et al. 2007). These guilds encompass species that nest or forage in the midstory, where deer are browsing, or are particularly sensitive to habitat quality. I chose vulnerable species by selecting those that past studies had found to be vulnerable to deer density, as well as choosing species that were in 2 or more of the vulnerable guilds (Table 2).

Because deer affect the vegetation, which affects songbirds, I performed vegetation surveys at all targeted point count locations. I was prohibited access to 8 sites by landowners but was able to collect data on the remaining 210 sites. To estimate vegetation cover and composition, I walked $25 \mathrm{~m}$ into the forest perpendicular to each count site. There, I established nested circular plots, estimating the percent and type of groundcover within 0.0004 ha, and counting the number of midstory stems (identified to species) within 0.004 ha. From this, I calculated the percent non-native stems in the midstory. I also estimated the basal area from the center of each plot at the 5 and 10 factor level, as a measure of forest structure. I used a $2.5 \mathrm{~m}$ tall Nudds board to estimate the vertical vegetation profile of the midstory. At each cardinal direction, I placed the board $15 \mathrm{~m}$ from the center of the plot and estimated the percent vegetation covering the board, then averaged the values for an estimate of vertical vegetation cover at each point (Nudds 1977). 
I conducted all my data analyses using SAS (version 9.1, Cary, NC) with an alpha level of 0.10. For the BBS data, I used a one-way ANOVA, blocking on year with percent forest cover within a $50 \mathrm{~m}$ buffer as a covariate, to determine if the relative abundance or species richness of vulnerable guilds was affected by deer density. For species that were detected on $\geq 25 \%$ ( $n=73$ of 291) of points, I used a one-way ANOVA, blocking on year with percent forest cover within a $50 \mathrm{~m}$ buffer as a covariate, to determine if bird abundance was affected by deer density. If I detected significance, I used a protected least significant differences analysis (LSD) to compare among density categories (Sokal and Rohlf 1995).

To determine whether deer density was affecting the detection probabilities of the birds counted in targeted surveys, I used Program DISTANCE 5.0 (Thomas et al. 2010). I found that detection probabilities were not affected by deer densities, so I left the raw counts unadjusted (Williams et al 2002). For all abundance analyses of targeted point counts, I used the maximum value from the 3 visits to each point. For these data, I again used a one-way ANOVA, blocking on year with percent forest cover within a $50 \mathrm{~m}$ buffer as a covariate, to determine if the abundance or richness of vulnerable guilds was affected by deer density. For species that were counted on $\geq 25 \%$ ( $n=106$ of 424) of points, I used a one-way ANOVA, blocking on year with percent forest cover within a $50 \mathrm{~m}$ buffer as a covariate, to determine if bird abundance was affected by deer density. I again used a protected LSD analysis to compare the mean number of species or birds between deer densities when I detected significance.

To further examine the effect of deer density on songbird species from targeted point count data, I used Program PRESENCE 2.3 (Hines 2006; http://www.mbrpwrc.gov/software/presence.html). I first defined a set of a priori models that could explain 
detection probability and site occupancy (Table 3). I started with a constant occupancy model and examined all the variables that could explain detection probability individually (survey, time, date, or constant detection). I chose the best model for detection for each species based on $\Delta$ AIC values (Burnham and Anderson 2002). I then modeled the best detection variable with the occupancy variables (deer density, percent forest cover in a $50 \mathrm{~m}$ buffer, an additive function of the two, year, a global model, and constant occupancy; MacKenzie 2006). I chose the best models for each species based on $\triangle \mathrm{AIC}$ or $\triangle \mathrm{QAIC}$ (to adjust for lack of fit) values. I then examined the $\beta$ values for the deer density variable for all species where it was a factor in one of the top models.

I used a one-way ANOVA to determine if deer density affected the vegetation variables I estimated, because vegetation is the main means by which deer would have an effect on songbirds. I analyzed the following vegetation variables: the percent grass, forbs, woody vegetation, organic matter, and bare soil in the groundcover, the basal area of a point (Factor 5 and 10), the percent of exotic midstory stems, and the vertical vegetation structure of a point. For each vegetation characteristic where significance was detected, I conducted a protected LSD analysis to compare means between deer densities. 
Table 1. Deer densities (deer $/ \mathrm{km}^{2}$ ) of the 17 deer management zones in Delaware as measured by the Delaware Division of Fish and Wildlife in 2005, 2009, an average of the 2 years. Density categories used for comparisons of avian relative abundance and species richness among deer densities.

\begin{tabular}{|c|c|c|c|c|}
\hline Zone & 2005 & 2009 & Average & Category \\
\hline 1 & 45 & 11 & 28 & High \\
\hline 2 & 17 & 10 & 13 & Moderate \\
\hline 3 & 13 & 4 & 8 & Low \\
\hline 4 & 14 & 4 & 9 & Low \\
\hline 5 & 15 & 2 & 9 & Low \\
\hline 6 & 5 & 5 & 5 & Low \\
\hline 7 & 32 & 8 & 20 & High \\
\hline 8 & 21 & 7 & 14 & Moderate \\
\hline 9 & 16 & 4 & 10 & Low \\
\hline 10 & 13 & 11 & 12 & Moderate \\
\hline 11 & 17 & 4 & 10 & Low \\
\hline 12 & 14 & 3 & 8 & Low \\
\hline 13 & 6 & 7 & 7 & Low \\
\hline 14 & 29 & 16 & 23 & High \\
\hline 15 & 21 & 5 & 13 & Moderate \\
\hline 16 & 32 & 8 & 20 & High \\
\hline 17 & 4 & 8 & 6 & Low \\
\hline
\end{tabular}


Table 2. Avian guilds (based on O'Connell et al. [1998] and Bishop and Meyers [2005]) and species vulnerable to high deer densities used for comparisons of avian relative abundance and species richness among deer densities categories. Species found to be sensitive to deer density in the reviewed literature are in bold.

\begin{tabular}{|c|c|c|c|c|c|c|c|}
\hline Species & $\begin{array}{l}\text { Interior } \\
\text { forest } \\
\text { obligate }\end{array}$ & $\begin{array}{l}\text { Ground } \\
\text { nester }\end{array}$ & $\begin{array}{l}\text { Shrub } \\
\text { nester }\end{array}$ & $\begin{array}{l}\text { Ground } \\
\text { gleaner }\end{array}$ & $\begin{array}{l}\text { Low } \\
\text { canopy } \\
\text { forager }\end{array}$ & $\begin{array}{l}\text { Neo-tropical } \\
\text { migrant }\end{array}$ & $\begin{array}{l}\text { Vulnerable } \\
\text { species }\end{array}$ \\
\hline $\begin{array}{l}\text { Acadian Flycatcher } \\
\text { Empidonax virescens }\end{array}$ & $X$ & & & & & $X$ & $X$ \\
\hline $\begin{array}{l}\text { American Goldfinch } \\
\text { Spinus tristis }\end{array}$ & & & $X$ & & & & \\
\hline $\begin{array}{l}\text { American Redstart } \\
\text { Setophaga ruticilla }\end{array}$ & $X$ & & & & $X$ & $X$ & $X$ \\
\hline $\begin{array}{l}\text { Baltimore Oriole } \\
\text { Icterus galbula }\end{array}$ & & & & & & $X$ & \\
\hline $\begin{array}{l}\text { Barn Swallow } \\
\text { Hirundo rustica }\end{array}$ & & & & & & $X$ & \\
\hline $\begin{array}{l}\text { Black-and-white Warbler } \\
\text { Mniotilta varia }\end{array}$ & X & $X$ & & & & $X$ & $X$ \\
\hline $\begin{array}{l}\text { Black-billed Cuckoo } \\
\text { Coccyzus erythropthalmus }\end{array}$ & & & $\mathbf{X}$ & & $\mathbf{X}$ & $\mathbf{X}$ & $\mathbf{X}$ \\
\hline $\begin{array}{l}\text { Blue Grosbeak } \\
\text { Passerina caerulea }\end{array}$ & & & X & & & $X$ & $X$ \\
\hline $\begin{array}{l}\text { Brown Thrasher } \\
\text { Toxostoma rufum }\end{array}$ & & & $X$ & & & & \\
\hline
\end{tabular}


Table 2. cont.

\begin{tabular}{|c|c|c|c|c|c|c|c|}
\hline 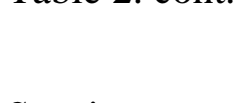 & $\begin{array}{l}\text { Interior } \\
\text { forest }\end{array}$ & $\begin{array}{l}\text { Ground } \\
\text { nester }\end{array}$ & $\begin{array}{l}\text { Shrub } \\
\text { nester }\end{array}$ & $\begin{array}{l}\text { Ground } \\
\text { gleaner }\end{array}$ & $\begin{array}{l}\text { Low } \\
\text { canopy }\end{array}$ & $\begin{array}{l}\text { Neo-tropical } \\
\text { migrant }\end{array}$ & $\begin{array}{l}\text { Vulnerable } \\
\text { species }\end{array}$ \\
\hline Species & obligate & & & & forager & & \\
\hline
\end{tabular}

Brown-headed Nuthatch

X

Sitta pusilla

Carolina Chickadee

Poecile carolinensis

Carolina Wren

Thryothorus ludovicianus

X

Chimney Swift

Chaetura pelagica

Chipping Sparrow

Spizella passerina

Chuck-will's-widow

Caprimulgus carolinensis

Common Yellowthroat

Geothlypis trichas

Eastern Kingbird

Tyrannus tyrannus

Eastern Towhee

Pipilo erythrophthalmus

Eastern Wood-Pewee

Contopus virens
$\mathbf{X}$

X

X

$\mathbf{X}$

$\mathbf{X}$

X

$\mathbf{X}$

X

$\mathbf{X}$ 
Table 2. cont.

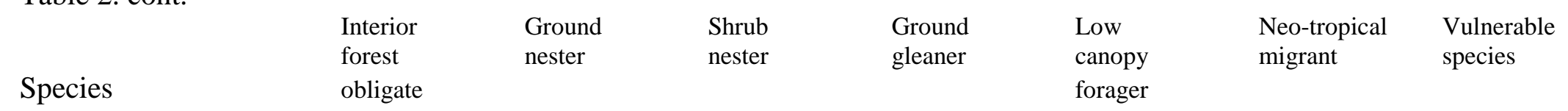

\section{Field Sparrow}

Spizella pusilla

Gray Catbird

X

Dumetella carolinensis

Great Crested Flycatcher

Myiarchis crinitus

X

Hairy Woodpecker

Picoides villosus

Hooded Warbler

X

$\mathbf{X}$

$\mathbf{X}$

$\mathbf{X}$

$\mathbf{X}$

House Wren

Troglodytes aedon

Indigo Bunting

Passerina cyanea

Kentucky Warbler

Oporornis formosus

$\mathbf{X}$

$\mathbf{X}$

$\mathbf{X}$

$\mathbf{X}$

$\mathbf{X}$

Louisiana Waterthrush

$\mathbf{X}$

$\mathbf{X}$

X

$\mathbf{X}$

X

Seiurus motacilla

Northern Cardinal

Cardinalis cardinalis

X 
Table 2. cont.

\begin{tabular}{|c|c|c|c|c|c|c|c|}
\hline Species & $\begin{array}{l}\text { Interior } \\
\text { forest } \\
\text { obligate }\end{array}$ & $\begin{array}{l}\text { Ground } \\
\text { nester }\end{array}$ & $\begin{array}{l}\text { Shrub } \\
\text { nester }\end{array}$ & $\begin{array}{l}\text { Ground } \\
\text { gleaner }\end{array}$ & $\begin{array}{l}\text { Low } \\
\text { canopy } \\
\text { forager }\end{array}$ & $\begin{array}{l}\text { Neo-tropical } \\
\text { migrant }\end{array}$ & $\begin{array}{l}\text { Vulnerable } \\
\text { species }\end{array}$ \\
\hline $\begin{array}{l}\text { Northern Flicker } \\
\text { Colaptes auratus }\end{array}$ & & & & $X$ & & & \\
\hline $\begin{array}{l}\text { Northern Mockingbird } \\
\text { Mimus polyglottos }\end{array}$ & & & $X$ & & & & \\
\hline $\begin{array}{l}\text { Northern Parula } \\
\text { Parula americana }\end{array}$ & & & & & & $X$ & \\
\hline $\begin{array}{l}\text { Orchard Oriole } \\
\text { Icterus spurious }\end{array}$ & & & & & & $X$ & \\
\hline $\begin{array}{l}\text { Ovenbird } \\
\text { Seiurus aurocapilla }\end{array}$ & $\mathbf{X}$ & $\mathbf{X}$ & & $\mathbf{X}$ & & $\mathbf{X}$ & $\mathbf{X}$ \\
\hline $\begin{array}{l}\text { Pileated Woodpecker } \\
\text { Dryocopus pileatus }\end{array}$ & $X$ & & & & & & \\
\hline $\begin{array}{l}\text { Pine Warbler } \\
\text { Dendroica pinus }\end{array}$ & $X$ & & & & & & \\
\hline $\begin{array}{l}\text { Prairie Warbler } \\
\text { Dendroica discolor }\end{array}$ & & & $X$ & & $X$ & $X$ & $X$ \\
\hline $\begin{array}{l}\text { Prothonotary Warbler } \\
\text { Protonotaria citrea }\end{array}$ & & & & & & $X$ & \\
\hline $\begin{array}{l}\text { Purple Martin } \\
\text { Progne subis }\end{array}$ & & & & & & $X$ & \\
\hline
\end{tabular}


Table 2. cont.

\begin{tabular}{|c|c|c|c|c|c|c|c|}
\hline 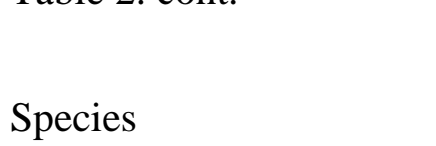 & $\begin{array}{l}\text { Interior } \\
\text { forest } \\
\text { obligate }\end{array}$ & $\begin{array}{l}\text { Ground } \\
\text { nester }\end{array}$ & $\begin{array}{l}\text { Shrub } \\
\text { nester }\end{array}$ & $\begin{array}{l}\text { Ground } \\
\text { gleaner }\end{array}$ & $\begin{array}{l}\text { Low } \\
\text { canopy } \\
\text { forager }\end{array}$ & $\begin{array}{l}\text { Neo-tropical } \\
\text { migrant }\end{array}$ & $\begin{array}{l}\text { Vulnerable } \\
\text { species }\end{array}$ \\
\hline $\begin{array}{l}\text { Red-eyed Vireo } \\
\text { Vireo olivaceus }\end{array}$ & & & $X$ & & & $X$ & $X$ \\
\hline $\begin{array}{l}\text { Red-winged Blackbird } \\
\text { Agelaius phoeniceus }\end{array}$ & & & $X$ & & & & \\
\hline $\begin{array}{l}\text { Ruby-throated Hummingbird } \\
\text { Archilochus colubris }\end{array}$ & & & & & & $X$ & \\
\hline $\begin{array}{l}\text { Scarlet Tanager } \\
\text { Piranga olivacea }\end{array}$ & $X$ & & & & & $X$ & $X$ \\
\hline $\begin{array}{l}\text { Summer Tanager } \\
\text { Piranga rubra }\end{array}$ & & & & & & $X$ & \\
\hline $\begin{array}{l}\text { Swamp Sparrow } \\
\text { Melospiza georgiana }\end{array}$ & & & $X$ & & & & \\
\hline $\begin{array}{l}\text { Tufted Titmouse } \\
\text { Baeolophus bicolor }\end{array}$ & & & & & $X$ & & \\
\hline $\begin{array}{l}\text { White-breasted Nuthatch } \\
\text { Sitta carolinensis }\end{array}$ & $X$ & & & & & & \\
\hline $\begin{array}{l}\text { White-eyed Vireo } \\
\text { Vireo griseus }\end{array}$ & & & $X$ & & $X$ & & $X$ \\
\hline $\begin{array}{l}\text { Willow Flycatcher } \\
\text { Empidonax trailii }\end{array}$ & & & $\mathbf{X}$ & & & $\mathbf{X}$ & $\mathbf{X}$ \\
\hline
\end{tabular}


Table 2. cont.

\begin{tabular}{|c|c|c|c|c|c|c|c|}
\hline Species & $\begin{array}{l}\text { Interior } \\
\text { forest } \\
\text { obligate }\end{array}$ & $\begin{array}{l}\text { Ground } \\
\text { nester }\end{array}$ & $\begin{array}{l}\text { Shrub } \\
\text { nester }\end{array}$ & $\begin{array}{l}\text { Ground } \\
\text { gleaner }\end{array}$ & $\begin{array}{l}\text { Low } \\
\text { canopy } \\
\text { forager }\end{array}$ & $\begin{array}{l}\text { Neo-tropical } \\
\text { migrant }\end{array}$ & $\begin{array}{l}\text { Vulnerable } \\
\text { species }\end{array}$ \\
\hline $\begin{array}{l}\text { Wood Thrush } \\
\text { Hylocichla mustelina }\end{array}$ & & & $\mathbf{X}$ & $\mathbf{X}$ & & $\mathbf{X}$ & $\mathbf{X}$ \\
\hline $\begin{array}{l}\text { Worm-eating Warbler } \\
\text { Helmitheros vermivorum }\end{array}$ & & $X$ & & $X$ & & $X$ & $X$ \\
\hline $\begin{array}{l}\text { Yellow Warbler } \\
\text { Dendroica petechia }\end{array}$ & & & $X$ & & $X$ & $X$ & $X$ \\
\hline $\begin{array}{l}\text { Yellow-billed Cuckoo } \\
\text { Coccyzus americanus }\end{array}$ & & & $\mathbf{X}$ & & $\mathbf{X}$ & $\mathbf{X}$ & $\mathbf{X}$ \\
\hline $\begin{array}{l}\text { Yellow-breasted Chat } \\
\text { Icteria virens }\end{array}$ & & & $X$ & & & $X$ & $X$ \\
\hline $\begin{array}{l}\text { Yellow-throated Vireo } \\
\text { Vireo flavifrons }\end{array}$ & & & & & & $\mathrm{X}$ & \\
\hline
\end{tabular}


Table 3. Models used to evaluate factors affecting occupancy for species counted in Delaware, 2008-2009. $\psi$ represents occupancy covariates, $p$ represents detection covariates.

\begin{tabular}{ll}
\hline Model & \multicolumn{1}{c}{ Description } \\
\hline$\psi($ deer density), $p$ (covariate) & $\begin{array}{l}\text { occupancy as a function of deer density and } \\
\text { detection as a function of the best modeled } \\
\text { covariate }\end{array}$ \\
$\psi($ deer density+forest), $p$ (covariate) & $\begin{array}{l}\text { occupancy as an additive function of deer density } \\
\text { and percent forest cover within a } 50 \text { m buffer and } \\
\text { detection as a function of the best modeled } \\
\text { covariate }\end{array}$ \\
$\psi($ forest), $p$ (covariate) & $\begin{array}{l}\text { occupancy as a function of percent forest cover } \\
\text { within a } 50 \text { m buffer and detection as a function of } \\
\text { the best modeled covariate }\end{array}$ \\
$\psi($ year), $p$ (covariate) & $\begin{array}{l}\text { occupancy as a function of the year of the survey } \\
\text { and detection as a function of the best modeled } \\
\text { covariate }\end{array}$ \\
global & $\begin{array}{l}\text { constant occupancy and detection as a function of } \\
\text { the best modeled covariate }\end{array}$ \\
& $\begin{array}{l}\text { occupancy as an additive function of all occupancy } \\
\text { covariates and detection as a function of all } \\
\text { detection covariates }\end{array}$ \\
\hline
\end{tabular}


Figure 2. Breeding Bird Survey (BBS) routes in Delaware, 2005-2008. Highlighted points have $>40 \%$ forest cover and were points used for comparisons of avian relative abundance and species richness at different deer densities. Background shading indicates deer density (light $=$ low, medium $=$ moderate, dark $=$ high ).

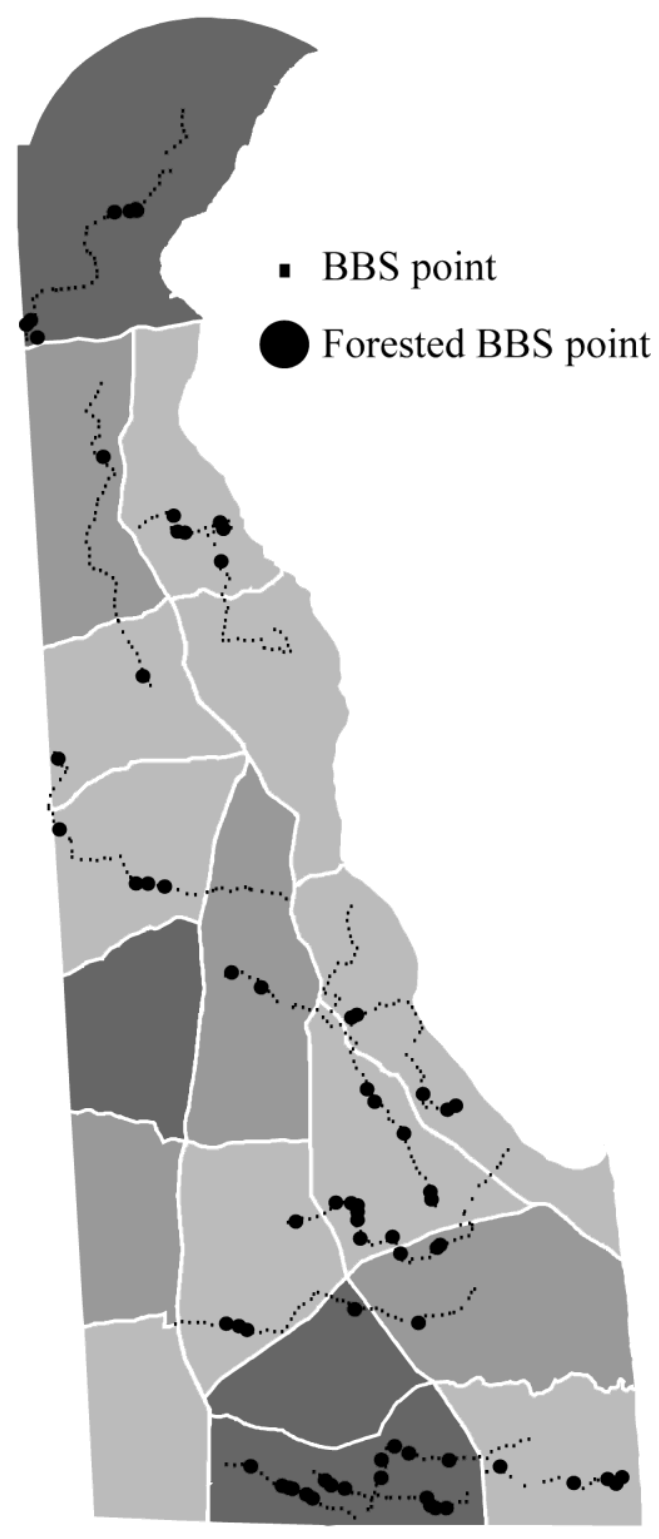


Figure 3. Location of targeted bird survey points in Delaware, 2008-2009, used for comparisons of avian relative abundance and species richness at different deer densities. Labels indicate number of points. Background shading indicates deer density (light $=$ low, medium $=$ moderate, dark = high).

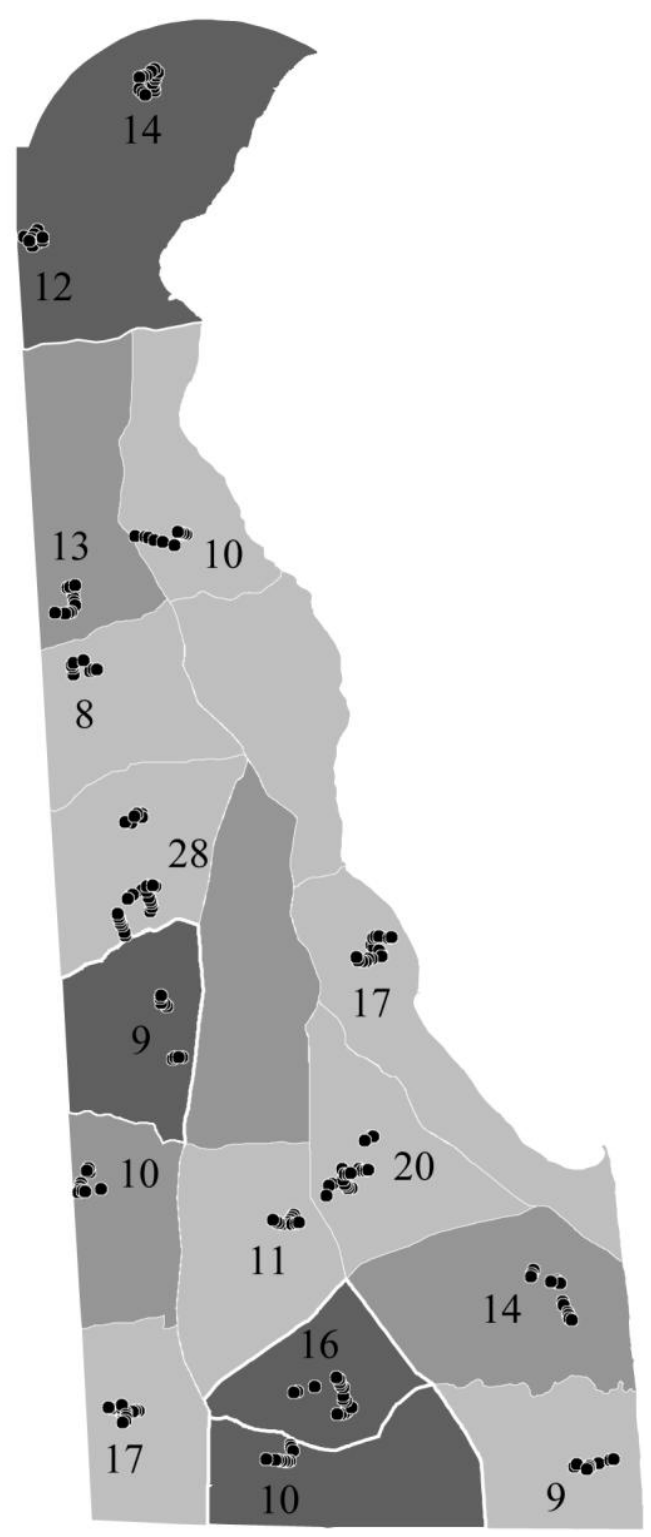




\section{Chapter 3}

\section{RESULTS}

For the BBS data, most (67\%) bird guilds were more abundant at low deer densities (Table 4). Low deer density areas had 1.08 more shrub nesters than high deer density areas and at least 0.56 more neo-tropical migrants than moderate or high deer density areas (Table 4). Low or moderate deer densities had at least 0.52 more individual low canopy foragers than high deer densities. I observed at least 0.61 more ground gleaners at low and high deer densities when compared to moderate deer densities. The abundances of interior forest obligates and ground nesters did not differ by deer density. Species richness also did not differ by deer density for half of the guilds (Table 4). However, low deer densities had 0.54 more species of shrub nesting birds than high deer densities and moderate and low deer densities had at least 0.36 more species of low canopy foragers than high deer densities. The species richness of ground gleaning birds was at least 0.24 species greater at high and low than at moderate deer densities. Only 2 (18\%) of the individual species' relative abundances differed by deer density (Table 5). I observed at least 0.29 more Acadian Flycatchers (Empidonax virescens) at moderate and low deer densities compared to high densities and at least 0.34 more Wood Thrushes (Hylocichla mustelina) at low and high deer densities compared to moderate densities.

For targeted point count data collected in deer density FLIR transects, the relative abundance and species richness of most (58\%) bird guilds did not differ by deer density (Table 6). Low deer densities had at least 0.59 more individual neo-tropical migrants compared to moderate or high deer densities. Similarly, low deer densities had at least 0.49 more migrant species than higher densities. However, I detected at least 0.29 more individual ground gleaners 
at high and low deer densities compared to moderate densities and at least 0.18 more ground gleaning species at high and low compared to moderate deer densities. Most (63\%) individual species, again, did not differ by deer density (Table 7). Of those that were, the majority ( $80 \%)$ were most abundant at lower deer densities. Low deer densities had 0.18 more Great Crested Flycatchers (Myiarchus crinitus) than high densities, and at least 0.17 more Ovenbirds (Seiurus aurocapillus) compared to high and moderate deer densities. Moderate or low density areas had at least 0.31 more Red-eyed Vireos (Vireo olivaceus) and at least 0.16 more Chipping Sparrows (Spizella passerina) than high deer densities. The exception was the Pine Warblers (Dendroica pinus), with high deer density areas having 0.18 more individuals than moderate density areas.

I was able to analyze 21 species using Program PRESENCE, after eliminating those with small sample size and lack of convergence. Of these, 16 species had top models where occupancy was not constant (and thus affected by one of the occupancy variables; Tables 3, 8). Eight species had deer density as a factor affecting occupancy (the 95\% CI of the odds ratio did not overlap 1), 6 of which were negatively affected by deer (Table 8 ). The most strongly affected was the Yellow-billed Cuckoo (Cосcyzus americanus), which had 15 times greater odds of being found in low than high deer densities. Common Yellowthroats (Geothlypis trichas) and Great Crested Flycatchers both had 3 times greater odds of being found in low deer density areas than in high density areas, while Acadian Flycatchers, Red-eyed Vireos, and Chipping Sparrows all had 2 times greater odds of being found in low deer density areas than high deer density areas. Conversely, high deer density areas had 3 times greater odds of being occupied by Wormeating Warblers (Helmitheros vermivorus) and 14 times greater odds of being occupied by Gray Catbirds (Dumatella carolinensis; Table 8). 
High deer density areas had at least $2 \%$ more bare soil in the groundcover compared to points at low densities. Exotic species made up at least $9 \%$ more of the midstory at high deer density areas than at moderate or low deer density areas. The same trend was seen with the vertical vegetation cover, which had at least $8 \%$ more midstory cover at high and moderate deer densities than at low densities. All other vegetation variables did not differ by deer density (Table 9).

\section{DISCUSSION}

I did not observe an effect of deer density on just over half (52\%) of all songbird guilds or species analyzed from BBS and targeted point count data. These results are in line with what DeCalesta (1994), McShea and Rappole (2000), and Casey and Hein (1983) documented in similar studies. However, deer density did affect certain sensitive birds. Almost all sensitive bird guilds that were affected by deer density, were affected negatively. Similarly, almost all individual species that had significant results were also present at greater numbers at lower deer densities. Although not all comparisons were significant, examining the trends in the other guilds and species revealed the same pattern of birds faring better in low and moderate deer density areas, and perhaps with a larger sample differences would have been detected for these species.

Neo-tropical migrants and shrub nesting birds, as guilds and the individual species, were consistently found with greater species richness and greater abundances in low deer densities. Many of the species in these guilds have been shown to be sensitive to deer density in past studies. Supporting my findings, Casey and Hein (1983) detected a lack of shrub nesters at high deer densities. Additionally, McShea and Rappole (2000) saw an increase in the abundance of Acadian Flycatchers and Great Crested Flycatchers, both neo-tropical migrants, after the 
exclusion of deer from an area. As individual species, I also found that these Flycatchers were most abundant at lower deer densities.

Alternatively, birds associated with the low canopy seemed to have a greater threshold tolerance for deer density. The relative abundance and species richness of this guild were still least at high deer densities, but were similar between low and moderate densities. DeCalesta (1994) observed a marked decrease in the abundance and richness of these birds at the highest deer densities, as well as a decrease in the abundance of Yellow-billed Cuckoos, a low canopy forager. Deer have been shown to greatly affect the regeneration rates of eastern hardwood trees at high densities (Tilghman 1989, Harlow and Downing 1970). In areas with high deer densities, deer could have sufficiently overbrowsed saplings so they never became tall enough to become a part of the lower canopy; thus reducing habitat for this guild.

Only ground gleaners showed a different trend, having greater relative abundance and species richness at both high and low deer densities compared to moderate densities. Close examination of the individual species in this guild offers potential explanations for this pattern. I analyzed 6 ground gleaners but only 2 (Wood Thrush and Ovenbird) are found at abundances great enough to influence the guild as a whole. Two ground gleaners, the Kentucky Warbler (Oporornis formosus) and the Louisiana Waterthrush (Seiurus motacilla), were rare birds and were seldom encountered in Delaware. The Northern Flicker (Colaptes auratus) and the Wormeating Warbler were more common than the warblers mentioned above, but still not common in Delaware. The Flicker is a ground feeding species that can adapt to open, park-like settings (Hess et al. 2000), so areas with high deer densities that have a degraded understory could create this sort of habitat. If flickers are consistently being found in high deer density areas the relative 
abundance and species richness of the guild they are a part of would be greater in these places. Worm-eating Warblers are mainly found in southern Delaware (Hess et al. 2000), which is where all but 1 of the high deer density zones are located (Figure 1). I think this species is responding to other cues that determine its presence (e.g. patch size; Robbins et al 1989), rather than deer density. The last 2 species are very common and are most likely the main drivers of abundance patterns seen in the ground gleaning guild. Wood Thrushes, like the guild as a whole, were most abundant at both low and high deer densities. Wood Thrushes are more adaptable than many songbirds and are less sensitive to forest fragmentation than most (Hess et al. 2000, Roth and Johnson 1993). Perhaps they are also not as sensitive to the quality of the forest midstory, so it is possible that Wood Thrushes are able to utilize exotic shrubs better than other species. Because Wood Thrushes were so numerous, they could easily affect the overall pattern of ground gleaner abundance. Conversely, Ovenbirds, the most common ground gleaner, were most abundant at low deer densities. The combination of the abundance patterns of Ovenbirds (greatest at low deer densities) and Wood Thrushes (greatest at high and low densities), plus the less abundant species (both greatest at high deer densities) could account for the odd trend seen in the ground gleaner guild.

Only 3 species (14\%) were only positively influenced by deer density, and all 3 have restricted ranges in Delaware. The Worm-eating Warbler, discussed above, is found only in southern Delaware where most high deer density areas are located (Figure 1). The Pine Warbler is also restricted to southern Delaware, due to the abundance of pine habitat. Finally, Gray Catbirds live almost exclusively in the Piedmont portion of Delaware. I only had 1 route on the Piedmont and it was in a high deer density area. None of these species are categorized in more 
than 2 sensitive guilds, so their restricted ranges are probably the reason they were found in high deer density areas, not their response to deer density, per se.

Despite the negative effects I saw in the bird community, I did not observe the expected trend of sparse vegetation cover in the midstory in areas with a high deer density. These areas did, however, have a greater percentage of exotic species compared to lower deer density areas. Eschtruth and Battles (2009) have shown that white-tailed deer can facilitate the spread of exotic and invasive plants in eastern forests. High deer density areas (particularly zone 1) have proportionally more exotic species which are potentially compensating for the decrease in native species; therefore, the midstory layer appears to be thicker in areas of high deer density. This thicker midstory could be due to the greater number of deer preferentially browsing native species. Exotic species have been shown to support far fewer insects and birds than native shrubs (Burghardt et al. 2009), so even though the midstory appears intact, it may not provide sufficient resources for birds. If birds cannot get the food resources they need or adequate nesting spots in a midstory dominated by exotic plants, then one would expect fewer of them in these areas, even when the midstory looks dense.

\section{MANAGEMENT IMPLICATIONS}

Most guilds and species were not impacted by deer density in Delaware, so I do not recommend any change in the current deer management goals. Only certain sensitive birds were affected when densities exceeded 20 deer $/ \mathrm{km}^{2}$, and not many areas in Delaware surpass that density. However, managers in these areas may want to consider reducing deer densities to below 20 deer $/ \mathrm{km}^{2}$ in order to provide adequate conditions for these sensitive avian species. Knowing how and why deer are impacting these birds is clearly important. More research needs 
to be done on the methods by which deer are affecting certain songbirds. The increase in exotic invasive species in high deer density areas is particularly interesting and warrants further research. 
Table 4. A comparison of mean relative abundance and species richness of guilds counted in the Delaware Breeding Bird Survey (BBS) during 2005-2009 among low, moderate and high deer densities. Values sharing the same letter within each row are not different.

\begin{tabular}{|c|c|c|c|c|c|c|c|c|}
\hline & \multicolumn{2}{|c|}{ Low } & \multicolumn{2}{|c|}{ Moderate } & \multicolumn{2}{|c|}{ High } & \multirow[b]{2}{*}{$\mathrm{F}_{2,190}$} & \multirow[b]{2}{*}{$P$} \\
\hline & $\overline{\bar{x}}$ & $\mathrm{SE}$ & $\overline{\bar{x}}$ & SE & $\overline{\bar{x}}$ & $\mathrm{SE}$ & & \\
\hline \multicolumn{9}{|l|}{ Relative abundance } \\
\hline Interior obligates & $1.60 \mathrm{a}$ & 0.141 & $1.26 \mathrm{a}$ & 0.300 & $1.22 \mathrm{a}$ & 0.208 & 3.13 & 0.046 \\
\hline Ground nesters & 0.74 & 0.082 & 0.29 & 0.095 & 0.47 & 0.094 & 0.23 & 0.794 \\
\hline Shrub nesters & $4.92 \mathrm{a}$ & 0.267 & $4.39 \mathrm{ab}$ & 0.492 & $3.84 \mathrm{~b}$ & 0.323 & 2.40 & 0.094 \\
\hline Ground gleaners & $1.25 \mathrm{a}$ & 0.114 & $0.65 b$ & 0.151 & $1.25 \mathrm{a}$ & 0.174 & 4.17 & 0.017 \\
\hline Low canopy foragers & $2.08 \mathrm{a}$ & 0.144 & $1.90 \mathrm{a}$ & 0.229 & $1.39 \mathrm{~b}$ & 0.145 & 12.14 & $<0.001$ \\
\hline Neo-tropical migrants & $4.98 \mathrm{a}$ & 0.274 & $4.16 b$ & 0.578 & $3.60 \mathrm{~b}$ & 0.309 & 2.69 & 0.070 \\
\hline \multicolumn{9}{|l|}{ Species richness } \\
\hline Interior obligates & 1.10 & 0.085 & 0.90 & 0.209 & 0.89 & 0.122 & 0.28 & 0.754 \\
\hline Ground nesters & 0.47 & 0.047 & 0.26 & 0.080 & 0.37 & 0.066 & 1.26 & 0.287 \\
\hline Shrub nesters & $3.28 \mathrm{a}$ & 0.145 & $3.06 \mathrm{ab}$ & 0.258 & $2.73 b$ & 0.186 & 2.64 & 0.074 \\
\hline Ground gleaners & $0.79 \mathrm{a}$ & 0.059 & $0.55 b$ & 0.121 & $0.93 \mathrm{a}$ & 0.113 & 3.02 & 0.051 \\
\hline Low canopy foragers & $1.45 \mathrm{a}$ & 0.085 & $1.48 \mathrm{a}$ & 0.179 & $1.10 \mathrm{~b}$ & 0.101 & 11.03 & $<0.001$ \\
\hline Neo-tropical migrants & 3.45 & 0.157 & 3.06 & 0.307 & 2.77 & 0.203 & 1.47 & 0.233 \\
\hline
\end{tabular}


Table 5. A comparison of mean relative abundance of bird species counted in the Delaware Breeding Bird Survey (BBS) during 2005-2008 among low, moderate and high deer densities. Species counted on at least $25 \%$ of points. Values sharing the same letter within each row are not different.

\begin{tabular}{|c|c|c|c|c|c|c|c|c|}
\hline & \multicolumn{2}{|c|}{ Low } & \multicolumn{2}{|c|}{ Moderate } & \multicolumn{2}{|c|}{ High } & \multirow[b]{2}{*}{$\mathrm{F}_{2,190}$} & \multirow[b]{2}{*}{$P$} \\
\hline & $\overline{\bar{x}}$ & SE & $\overline{\bar{x}}$ & SE & $\overline{\bar{x}}$ & SE & & \\
\hline Acadian Flycatcher & $0.41 \mathrm{a}$ & 0.060 & $0.42 \mathrm{a}$ & 0.166 & $0.12 b$ & 0.036 & 19.44 & $<0.001$ \\
\hline American Goldfinch & 0.53 & 0.067 & 0.65 & 0.158 & 0.31 & 0.064 & 0.49 & 0.612 \\
\hline Blue Grosbeak & 0.34 & 0.051 & 0.42 & 0.090 & 0.25 & 0.076 & 0.32 & 0.724 \\
\hline Carolina Wren & 0.38 & 0.050 & 0.42 & 0.111 & 0.39 & 0.074 & 0.78 & 0.462 \\
\hline Indigo Bunting & 0.73 & 0.077 & 0.52 & 0.160 & 0.76 & 0.098 & 0.08 & 0.922 \\
\hline Northern Cardinal & 0.59 & 0.063 & 0.87 & 0.216 & 0.46 & 0.085 & 0.38 & 0.685 \\
\hline Ovenbird & 0.56 & 0.069 & 0.19 & 0.086 & 0.36 & 0.080 & 0.80 & 0.453 \\
\hline Pine Warbler & $0.32 \mathrm{a}$ & 0.049 & $0.32 \mathrm{a}$ & 0.117 & $0.37 \mathrm{a}$ & 0.076 & 3.08 & 0.049 \\
\hline Red-eyed Vireo & 0.47 & 0.063 & 0.45 & 0.201 & 0.25 & 0.060 & 0.04 & 0.965 \\
\hline Tufted Titmouse & 0.47 & 0.065 & 0.58 & 0.166 & 0.25 & 0.079 & 1.78 & 0.172 \\
\hline Wood Thrush & $0.56 \mathrm{a}$ & 0.073 & $0.13 b$ & 0.077 & $0.47 \mathrm{a}$ & 0.090 & 2.69 & 0.071 \\
\hline
\end{tabular}


Table 6. A comparison of mean relative abundance and species richness of guilds encountered in Delaware on point counts during 2008-2009 among low, moderate and high deer densities. Values sharing the same letter within each row are not different.

\begin{tabular}{|c|c|c|c|c|c|c|c|c|}
\hline & \multicolumn{2}{|c|}{ Low } & \multicolumn{2}{|c|}{ Moderate } & \multicolumn{2}{|c|}{ High } & \multirow[b]{2}{*}{$\mathrm{F}_{2,418}$} & \multirow[b]{2}{*}{$P$} \\
\hline & $\bar{x}$ & SE & $\bar{x}$ & SE & $\bar{x}$ & SE & & \\
\hline \multicolumn{9}{|l|}{ Relative abundance } \\
\hline Interior obligates & $2.20 \mathrm{a}$ & 0.095 & $1.92 \mathrm{a}$ & 0.163 & $1.98 \mathrm{a}$ & 0.160 & 2.48 & 0.085 \\
\hline Ground nesters & 1.19 & 0.063 & 1.01 & 0.104 & 0.98 & 0.083 & 2.10 & 0.123 \\
\hline Shrub nesters & 5.40 & 0.137 & 5.23 & 0.228 & 5.34 & 0.182 & 0.20 & 0.821 \\
\hline Ground gleaners & $1.49 \mathrm{a}$ & 0.082 & $1.20 \mathrm{~b}$ & 0.082 & $1.58 \mathrm{a}$ & 0.139 & 5.10 & 0.007 \\
\hline Low canopy foragers & 3.30 & 0.116 & 3.14 & 0.177 & 3.18 & 0.166 & 0.36 & 0.699 \\
\hline Neo-tropical migrants & $5.24 \mathrm{a}$ & 0.155 & $4.65 b$ & 0.281 & $4.47 b$ & 0.230 & 3.79 & 0.023 \\
\hline \multicolumn{9}{|l|}{ Species richness } \\
\hline Interior obligates & $1.83 \mathrm{a}$ & 0.071 & $1.58 \mathrm{~b}$ & 0.122 & $1.63 b$ & 0.106 & 3.02 & 0.050 \\
\hline Ground nesters & 0.95 & 0.045 & 0.84 & 0.077 & 0.82 & 0.069 & 1.75 & 0.175 \\
\hline Shrub nesters & 4.26 & 0.102 & 3.88 & 0.176 & 4.13 & 0.146 & 1.50 & 0.224 \\
\hline Ground gleaners & $1.14 \mathrm{a}$ & 0.052 & $0.96 b$ & 0.085 & $1.23 \mathrm{a}$ & 0.096 & 4.66 & 0.010 \\
\hline Low canopy foragers & 2.57 & 0.080 & 2.50 & 0.134 & 2.42 & 0.121 & 1.33 & 0.267 \\
\hline Neo-tropical migrants & $4.26 \mathrm{a}$ & 0.117 & $3.77 b$ & 0.210 & $3.77 b$ & 0.183 & 3.76 & 0.024 \\
\hline
\end{tabular}


Table 7. A comparison of mean relative abundance of birds counted in Delaware on point counts during 2008-2009 among low, moderate and high deer densities. Species counted on at least $25 \%$ of points. Values sharing the same letter within each row are not different.

\begin{tabular}{|c|c|c|c|c|c|c|c|c|}
\hline & \multicolumn{2}{|c|}{ Low } & \multicolumn{2}{|c|}{ Moderate } & \multicolumn{2}{|c|}{ High } & \multirow[b]{2}{*}{$\mathrm{F}_{2,418}$} & \multirow[b]{2}{*}{$P$} \\
\hline & $\bar{x}$ & SE & $\bar{x}$ & SE & $\bar{x}$ & SE & & \\
\hline Acadian Flycatcher & 0.48 & 0.039 & 0.49 & 0.080 & 0.30 & 0.058 & 1.51 & 0.222 \\
\hline American Goldfinch & 0.77 & 0.045 & 0.97 & 0.110 & 0.78 & 0.074 & 1.95 & 0.144 \\
\hline Carolina Chickadee & 0.69 & 0.064 & 0.76 & 0.096 & 0.72 & 0.085 & 0.35 & 0.702 \\
\hline Carolina Wren & 0.56 & 0.041 & 0.58 & 0.072 & 0.64 & 0.065 & 0.61 & 0.543 \\
\hline Chipping Sparrow & $0.50 \mathrm{a}$ & 0.046 & $0.51 \mathrm{a}$ & 0.082 & $0.34 \mathrm{~b}$ & 0.059 & 3.91 & 0.021 \\
\hline Eastern Towhee & 0.28 & 0.034 & 0.36 & 0.068 & 0.26 & 0.049 & 0.84 & 0.432 \\
\hline Eastern Wood-Pewee & 0.37 & 0.035 & 0.34 & 0.059 & 0.34 & 0.052 & 0.10 & 0.909 \\
\hline Great Crested Flycatcher & $0.41 \mathrm{a}$ & 0.046 & $0.31 \mathrm{ab}$ & 0.066 & $0.23 b$ & 0.048 & 3.15 & 0.044 \\
\hline Indigo Bunting & 0.51 & 0.047 & 0.35 & 0.071 & 0.61 & 0.075 & 1.71 & 0.182 \\
\hline Northern Cardinal & 1.02 & 0.054 & 1.07 & 0.089 & 1.17 & 0.078 & 0.89 & 0.410 \\
\hline Ovenbird & $0.85 \mathrm{a}$ & 0.051 & $0.65 b$ & 0.080 & $0.68 b$ & 0.071 & 3.60 & 0.028 \\
\hline Pine Warbler & $0.38 \mathrm{ab}$ & 0.040 & $0.27 b$ & 0.065 & $0.45 \mathrm{a}$ & 0.075 & 4.11 & 0.017 \\
\hline Red-eyed Vireo & $0.88 \mathrm{a}$ & 0.048 & $0.89 a$ & 0.105 & $0.57 b$ & 0.060 & 3.82 & 0.023 \\
\hline Tufted Titmouse & 1.03 & 0.055 & 0.99 & 0.101 & 1.02 & 0.104 & 0.12 & 0.889 \\
\hline White-eyed Vireo & 0.35 & 0.034 & 0.28 & 0.062 & 0.31 & 0.046 & 0.39 & 0.675 \\
\hline Wood Thrush & 0.37 & 0.048 & 0.27 & 0.073 & 0.43 & 0.081 & 1.26 & 0.284 \\
\hline
\end{tabular}


Table 8. Parameter estimates (ß) and standard errors (SE) of occupancy models for species counted in Delaware, 2008-2009. Models are listed by $\triangle \mathrm{AIC}$ or $\triangle \mathrm{QAIC}$ when there was more than one well-supported model $(\triangle \mathrm{AIC}$ or $\Delta \mathrm{QAIC} \leq 2)$ for a species. Species are listed by increasing deer density $\beta$, followed by species whose occupancy was not affected by deer and those with constant occupancy.

\begin{tabular}{|c|c|c|c|c|c|c|c|c|}
\hline \multirow[t]{3}{*}{ Species } & \multicolumn{6}{|c|}{ Parameter } & & \\
\hline & \multicolumn{2}{|c|}{ Deer density } & \multicolumn{2}{|c|}{ Forest } & \multicolumn{2}{|c|}{ Year } & \multicolumn{2}{|c|}{$\underline{\text { Intercept }}$} \\
\hline & B & $\mathrm{SE}$ & $ß$ & SE & B & SE & ß & SE \\
\hline \multirow[t]{2}{*}{ Yellow-billed Cuckoo } & -1.31 & 0.327 & 0.02 & 0.008 & & & -0.15 & 1.092 \\
\hline & -1.44 & 0.431 & & & & & 2.33 & 1.268 \\
\hline Common Yellowthroat & -0.57 & 0.187 & -0.02 & 0.005 & & & 0.97 & 0.506 \\
\hline \multirow[t]{2}{*}{ Great Crested Flycatcher } & -0.54 & 0.209 & & & & & 1.10 & 0.553 \\
\hline & -0.56 & 0.211 & $<-0.01$ & 0.005 & & & 1.47 & 0.688 \\
\hline Acadian Flycatcher & -0.41 & 0.138 & 0.02 & 0.003 & & & -1.52 & 0.323 \\
\hline \multirow[t]{2}{*}{ Chipping Sparrow } & -0.37 & 0.160 & -0.02 & 0.003 & 0.22 & 0.269 & 1.80 & 0.560 \\
\hline & -0.33 & 0.154 & -0.01 & 0.003 & & & 1.81 & 0.390 \\
\hline Red-eyed Vireo & -0.36 & 0.157 & 0.02 & 0.005 & 0.43 & 0.275 & -0.53 & 0.654 \\
\hline \multirow[t]{2}{*}{ Scarlet Tanager } & & & 0.03 & 0.005 & & & -2.61 & 0.471 \\
\hline & -0.23 & 0.233 & 0.02 & 0.005 & & & -2.11 & 0.655 \\
\hline \multirow[t]{4}{*}{ Ovenbird } & & & 0.04 & 0.836 & & & -2.19 & 0.718 \\
\hline & -0.22 & 0.165 & 0.03 & 0.008 & & & -1.73 & 0.825 \\
\hline & -0.20 & 0.160 & 0.03 & 0.007 & -0.18 & 0.287 & -1.49 & 0.821 \\
\hline & \multicolumn{8}{|c|}{32} \\
\hline
\end{tabular}


Table 8. cont.

\begin{tabular}{|c|c|c|c|c|c|c|c|c|}
\hline & \multicolumn{2}{|c|}{ Deer density } & \multicolumn{2}{|c|}{ Forest } & \multicolumn{2}{|c|}{ Year } & \multicolumn{2}{|c|}{ Intercept } \\
\hline & $\beta$ & $\mathrm{SE}$ & $\beta$ & $\mathrm{SE}$ & $\beta$ & $\mathrm{SE}$ & $ß$ & $\mathrm{SE}$ \\
\hline \multirow[t]{2}{*}{ White-eyed Vireo } & & & & & -0.85 & 0.254 & 0.87 & 0.422 \\
\hline & -0.11 & 0.150 & -0.01 & 0.003 & -0.91 & 0.258 & 2.05 & 0.561 \\
\hline Pine Warbler & -0.09 & 0.175 & 0.03 & 0.004 & -0.40 & 0.311 & -1.47 & 0.687 \\
\hline \multirow[t]{2}{*}{ Black-and-white Warbler } & & & 0.027 & 0.005 & & & -3.23 & 0.479 \\
\hline & 0.19 & 0.236 & 0.03 & 0.005 & & & -3.65 & 0.611 \\
\hline \multirow[t]{2}{*}{ House Wren } & & & -0.03 & 0.014 & & & 0.41 & 1.101 \\
\hline & 0.28 & 0.252 & -0.03 & 0.015 & & & -0.25 & 1.470 \\
\hline \multirow[t]{3}{*}{ Northern Flicker } & & & -0.82 & 0.007 & & & 81.16 & 0.695 \\
\hline & 0.44 & 0.389 & -0.03 & 0.007 & & & 0.78 & 1.023 \\
\hline & & & & & -2.10 & 2.736 & 3.77 & 8.627 \\
\hline Worm-eating Warbler & 0.46 & 0.185 & 0.02 & 0.004 & -0.89 & 0.326 & -2.05 & 0.655 \\
\hline Gray Catbird & 1.30 & 0.287 & -0.04 & 0.008 & -0.24 & 0.450 & 0.51 & 1.020 \\
\hline Eastern Wood-Pewee & & & & & -0.87 & 0.249 & 0.98 & 0.413 \\
\hline \multirow[t]{2}{*}{ Blue Grosbeak } & & & & & -0.50 & 0.321 & 0.34 & 0.585 \\
\hline & & & & & & & -0.42 & 0.267 \\
\hline
\end{tabular}


Table 8. cont.

\begin{tabular}{|c|c|c|c|c|c|c|c|c|}
\hline & \multicolumn{2}{|c|}{ Deer density } & \multicolumn{2}{|c|}{ Forest } & \multicolumn{2}{|c|}{ Year } & \multicolumn{2}{|c|}{ Intercept } \\
\hline & $\bar{B}$ & $\mathrm{SE}$ & $\bar{\beta}$ & $\mathrm{SE}$ & $\bar{B}$ & SE & $\bar{B}$ & SE \\
\hline \multirow[t]{4}{*}{ Eastern Towhee } & & & & & & & -0.49 & 0.180 \\
\hline & & & $<0.01$ & 0.003 & & & -0.72 & 0.274 \\
\hline & & & & & 0.05 & 0.266 & -0.56 & 0.441 \\
\hline & -0.03 & 0.157 & & & & & -0.43 & 0.322 \\
\hline \multirow[t]{4}{*}{ Indigo Bunting } & & & -0.01 & 0.003 & & & 0.68 & 0.242 \\
\hline & & & & & & & -0.17 & 0.130 \\
\hline & & & & & -0.30 & 0.231 & 0.28 & 0.376 \\
\hline & 0.01 & 0.136 & -0.01 & 0.003 & & & 0.65 & 0.338 \\
\hline \multirow[t]{4}{*}{ Summer Tanager } & & & & & & & -1.33 & 0.430 \\
\hline & & & & & -0.44 & 0.416 & -0.67 & 0.772 \\
\hline & -0.26 & 0.248 & & & & & -0.90 & 0.600 \\
\hline & & & 0.01 & 0.006 & & & -2.09 & 0.497 \\
\hline \multirow[t]{3}{*}{ Tufted Titmouse } & & & & & & & 1.95 & 0.321 \\
\hline & -0.42 & 0.287 & & & & & 2.72 & 0.727 \\
\hline & & & & & 0.63 & 0.542 & 1.03 & 0.739 \\
\hline
\end{tabular}


Table 9. A comparison of vegetation characteristics estimated in Delaware, 2008-2009, from low, moderate, and high deer densities. Values sharing the same letter within each row are not different.

\begin{tabular}{|c|c|c|c|c|c|c|c|c|}
\hline & \multicolumn{2}{|c|}{ Low } & \multicolumn{2}{|c|}{ Moderate } & \multicolumn{2}{|c|}{ High } & \multirow[b]{2}{*}{$\mathrm{F}_{2,207}$} & \multirow[b]{2}{*}{$P$} \\
\hline & $\bar{x}$ & SE & $\bar{x}$ & SE & $\bar{x}$ & $\mathrm{SE}$ & & \\
\hline \multicolumn{9}{|c|}{ Groundcover component (\%) } \\
\hline Grass & 3.32 & 1.111 & 2.69 & 2.093 & 5.53 & 2.286 & 0.65 & 0.525 \\
\hline Forbs & 6.38 & 1.264 & 10.03 & 3.171 & 4.92 & 1.300 & 1.58 & 0.208 \\
\hline Woody vegetation & 20.85 & 2.072 & 18.44 & 3.625 & 16.05 & 2.173 & 1.08 & 0.342 \\
\hline Organic matter & 69.28 & 2.598 & 67.25 & 5.170 & 70.10 & 3.666 & 0.11 & 0.892 \\
\hline Soil & $0.17 \mathrm{~b}$ & 0.070 & $1.58 \mathrm{~b}$ & 1.175 & $3.40 \mathrm{a}$ & 1.065 & 7.36 & 0.001 \\
\hline Vertical vegetation cover & r $32.60 b$ & 1.754 & $40.10 \mathrm{a}$ & 3.712 & $42.40 \mathrm{a}$ & 3.164 & 4.80 & 0.009 \\
\hline Percent exotics & $1.57 \mathrm{~b}$ & 0.667 & $2.93 b$ & 1.504 & $12.13 \mathrm{a}$ & 3.293 & 10.00 & $<0.001$ \\
\hline \multicolumn{9}{|l|}{ Basal area } \\
\hline Factor 5 & 115.18 & 3.249 & 110.76 & 6.752 & 119.63 & 5.193 & 0.66 & 0.520 \\
\hline Factor 10 & 152.76 & 4.123 & 145.56 & 9.493 & 151.50 & 7.064 & 0.29 & 0.748 \\
\hline
\end{tabular}




\section{APPENDICES}

Appendix A. Number of detections, by species, from low, moderate and high deer densities, during point counts in Delaware, May-July 2008-2009.

Deer density

\begin{tabular}{|c|c|c|c|c|c|}
\hline Common name & Scientific name & High & Moderate & Low & Total \\
\hline Northern Cardinal & Cardinalis cardinalis & 267 & 193 & 555 & 1015 \\
\hline Tufted Titmouse & Baeolophus bicolor & 222 & 162 & 566 & 950 \\
\hline Ovenbird & Seiurus aurocapilla & 175 & 137 & 536 & 848 \\
\hline Red-eyed Vireo & Vireo olivaceus & 119 & 150 & 443 & 712 \\
\hline American Crow & Corvus brahyrhynchos & 199 & 104 & 373 & 676 \\
\hline American Goldfinch & Spinus tristis & 138 & 136 & 320 & 594 \\
\hline Brown-headed Cowbird & Molothrus ater & 136 & 101 & 340 & 577 \\
\hline Carolina Wren & Thryothorus ludovicianus & 145 & 90 & 266 & 501 \\
\hline Indigo Bunting & Passerina cyanea & 147 & 54 & 280 & 481 \\
\hline Wood Thrush & Hylocichla mustelina & 134 & 71 & 276 & 481 \\
\hline Carolina Chickadee & Poecile carolinensis & 114 & 81 & 231 & 426 \\
\hline Blue Jay & Cyanocitta cristata & 92 & 38 & 149 & 412 \\
\hline Eastern Wood-pewee & Contopus virens & 86 & 79 & 233 & 398 \\
\hline Acadian Flycatcher & Empidonax virescens & 74 & 81 & 241 & 396 \\
\hline Chipping Sparrow & Spizella passerina & 68 & 87 & 224 & 379 \\
\hline American Robin & Turdus migratorius & 142 & 69 & 155 & 366 \\
\hline Great Crested Flycatcher & Myiarchis crinitus & 63 & 50 & 205 & 318 \\
\hline Red-bellied Woodpecker & Melanerpes carolinus & 70 & 56 & 177 & 303 \\
\hline Blue Grosbeak & Passerina caerulea & 47 & 30 & 104 & 279 \\
\hline White-eyed Vireo & Vireo griseus & 71 & 35 & 171 & 277 \\
\hline
\end{tabular}




\begin{tabular}{|c|c|c|c|c|c|}
\hline Common Grackle & Quiscalus quiscula & 62 & 56 & 152 & 270 \\
\hline Pine Warbler & Dendroica pinus & 86 & 31 & 152 & 269 \\
\hline Eastern Towhee & Pipilo erythrophthalmus & 60 & 67 & 141 & 268 \\
\hline Mourning Dove & Zenaida macroura & 60 & 33 & 119 & 212 \\
\hline Blue-gray Gnatcatcher & Polioptila caerulea & 89 & 64 & 259 & 181 \\
\hline Yellow-billed Cuckoo & Coccyzus americanus & 25 & 22 & 137 & 166 \\
\hline Downy Woodpecker & Picoides pubescens & 38 & 30 & 97 & 165 \\
\hline Common Yellowthroat & Geothlypis trichas & 25 & 13 & 112 & 150 \\
\hline Scarlet Tanager & Piranga olivacea & 26 & 30 & 92 & 148 \\
\hline Worm-eating Warbler & Helmitheros vermivorum & 49 & 28 & 66 & 143 \\
\hline Gray Catbird & Dumetella carolinensis & 106 & 4 & 22 & 132 \\
\hline Laughing Gull & Leucophaeus atricilla & 40 & 35 & 49 & 124 \\
\hline Cedar Waxwing & Bombycilla cedrorum & 22 & 21 & 63 & 106 \\
\hline Northern Flicker & Colaptes auratus & 28 & 14 & 48 & 90 \\
\hline Prairie Warbler & Dendroica discolor & 27 & 36 & 19 & 82 \\
\hline Yellow-breasted Chat & Icteria virens & 18 & 4 & 53 & 75 \\
\hline Hairy Woodpecker & Picoides villosus & 17 & 8 & 42 & 67 \\
\hline Black-and-white Warbler & Mniotilta varia & 16 & 15 & 33 & 64 \\
\hline Red-winged Blackbird & Agelaius phoeniceus & 13 & 13 & 36 & 62 \\
\hline House Wren & Troglodytes aedon & 28 & 5 & 28 & 61 \\
\hline Field Sparrow & Spizella pusilla & 14 & 14 & 31 & 59 \\
\hline White-breasted Nuthatch & Sitta carolinensis & 31 & 14 & 14 & 59 \\
\hline Canada Goose & Branta canadensis & 20 & 1 & 36 & 57 \\
\hline Fish Crow & Corvus ossifragus & 6 & 16 & 30 & 52 \\
\hline Summer Tanager & Piranga rubra & 13 & 2 & 37 & 52 \\
\hline Brown Thrasher & Toxostoma rufum & 3 & 15 & 26 & 44 \\
\hline
\end{tabular}




\begin{tabular}{|c|c|c|c|c|c|}
\hline Pileated Woodpecker & Dryocopus pileatus & 10 & 3 & 25 & 38 \\
\hline Ruby-throated Hummingbird & Archilochus colubris & 11 & 7 & 20 & 38 \\
\hline Song Sparrow & Melospiza melodia & 28 & 1 & 2 & 31 \\
\hline Yellow-throated Vireo & Vireo flavifrons & 6 & 12 & 12 & 30 \\
\hline Eastern Phoebe & Sayornis phoebe & 11 & 2 & 15 & 28 \\
\hline Purple Martin & Progne subis & 10 & 2 & 16 & 28 \\
\hline Northern Bobwhite & Colinus virginianus & 4 & 1 & 22 & 27 \\
\hline Northern Mockingbird & Mimus polyglottos & 10 & 3 & 13 & 26 \\
\hline Kentucky Warbler & Oporornis formosus & 6 & 0 & 16 & 22 \\
\hline Turkey Vulture & Cathartes aura & 2 & 5 & 15 & 22 \\
\hline Blackpoll Warbler & Dendroica striata & 1 & 9 & 7 & 17 \\
\hline Wild Turkey & Meleagris gallopavo & 0 & 5 & 12 & 17 \\
\hline Veery & Catharus fuscescens & 10 & 1 & 5 & 16 \\
\hline Great Blue Heron & Ardea herodias & 3 & 4 & 8 & 15 \\
\hline Mallard & Anas platyrhynchos & 4 & 4 & 6 & 14 \\
\hline Yellow Warbler & Dendroica petechia & 2 & 5 & 7 & 14 \\
\hline Baltimore Oriole & Icterus galbula & 8 & 1 & 4 & 13 \\
\hline Double-crested Cormorant & Phalacrocorax auritus & 1 & 1 & 10 & 12 \\
\hline American Redstart & Setophaga ruticilla & 6 & 1 & 3 & 10 \\
\hline Chimney Swift & Chaetura pelagica & 2 & 4 & 4 & 10 \\
\hline House Sparrow & Passer domesticus & 4 & 4 & 2 & 10 \\
\hline Barn Swallow & Hirundo rustica & 2 & 3 & 4 & 9 \\
\hline House Finch & Carpodacus mexicanus & 7 & 0 & 2 & 9 \\
\hline Northern Parula & Parula americana & 5 & 0 & 4 & 9 \\
\hline Osprey & Pandion haliaetus & 2 & 7 & 0 & 9 \\
\hline Eastern Kingbird & Tyrannus tyrannus & 3 & 0 & 5 & 8 \\
\hline
\end{tabular}




\begin{tabular}{|c|c|c|c|c|c|}
\hline European Starling & Sturnus vulgaris & 3 & 0 & 5 & 8 \\
\hline Killdeer & Charadrius vociferus & 1 & 3 & 4 & 8 \\
\hline Eastern Bluebird & Sialia sialis & 3 & 0 & 4 & 7 \\
\hline Louisiana Waterthrush & Seiurus motacilla & 2 & 0 & 4 & 6 \\
\hline Marsh Wren & Cistothorus palustris & 0 & 2 & 3 & 5 \\
\hline Prothonotary Warbler & Protonotaria citrea & 0 & 1 & 4 & 5 \\
\hline Swamp Sparrow & Melospiza georgiana & 0 & 0 & 5 & 5 \\
\hline Red-headed Woodpecker & $\begin{array}{l}\text { Melanerpes } \\
\text { erythrocephalus }\end{array}$ & 3 & 0 & 1 & 4 \\
\hline Yellow-rumped Warbler & Dendroica coronata & 3 & 1 & 0 & 4 \\
\hline Black-billed Cuckoo & $\begin{array}{l}\text { Coccyzus } \\
\text { erythropthalmus }\end{array}$ & 1 & 0 & 2 & 3 \\
\hline Cooper's Hawk & Accipiter cooperii & 2 & 1 & 0 & 3 \\
\hline Red-tailed Hawk & Buteo jamaicensis & 1 & 0 & 2 & 3 \\
\hline Brown-headed Nuthatch & Sitta pusilla & 0 & 1 & 1 & 2 \\
\hline Golden Pheasant & Chrysolophus pictus & 2 & 0 & 0 & 2 \\
\hline Great Horned Owl & Bubo virginianus & 0 & 0 & 2 & 2 \\
\hline Green Heron & Butorides virescens & 0 & 0 & 2 & 2 \\
\hline Orchard Oriole & Icterus spurious & 0 & 0 & 2 & 2 \\
\hline Snowy Egret & Egretta thula & 0 & 2 & 0 & 2 \\
\hline Swainson's Thrush & Catharus ustulatus & 0 & 0 & 2 & 2 \\
\hline Tree Swallow & Tachycineta bicolor & 0 & 1 & 1 & 2 \\
\hline White-throated Sparrow & Zonotrichia albicollis & 0 & 0 & 2 & 2 \\
\hline Willet & Tringa semipalmata & 0 & 0 & 2 & 2 \\
\hline Willow Flycatcher & Empidonax trailii & 1 & 0 & 1 & 2 \\
\hline Bald Eagle & Haliaeetus leucocephalus & 0 & 0 & 1 & 1 \\
\hline Barn Owl & Tyto alba & 0 & 1 & 0 & 1 \\
\hline
\end{tabular}




\begin{tabular}{llllll|}
\hline Black-throated Green Warbler & Dendroica virens & 0 & 0 & 1 & 1 \\
\hline Chuck-will's-widow & Caprimulgus carolinensis & 0 & 0 & 1 & 1 \\
\hline Great Egret & Ardea alba & 0 & 1 & 0 & 1 \\
\hline Herring Gull & Larus argentatus & 0 & 1 & 0 & 1 \\
\hline Hooded Warbler & Wilsonia citrine & 1 & 0 & 0 & 1 \\
Magnolia Warbler & Dendroica magnolia & 0 & 0 & 1 & 1 \\
\hline Red-shouldered Hawk & Buteo lineatus & 1 & 0 & 0 & 1 \\
\hline Sharp-shinned Hawk & Accipiter striatus & 1 & 0 & 0 & 1 \\
\hline Whip-poor-will & Caprimulgus vociferus & 0 & 0 & 1 & 1 \\
\hline Wood Duck & Aix sponsa & 1 & 0 & 0 & 1 \\
\hline
\end{tabular}


Appendix B. Midstory plant species (native and exotic) encountered during vegetation surveys of point count sites in Delaware, July-August 2008-2009.

\begin{tabular}{|c|c|c|}
\hline Common name & Scientific name & Exotic \\
\hline Japanese maple & Acer palmatum & $\mathbf{X}$ \\
\hline Norway maple & Acer platanoides & $\mathbf{X}$ \\
\hline red maple & Acer rubrum & \\
\hline sugar maple & Acer saccharum & \\
\hline downy serviceberry & Amelanchier arborea & \\
\hline smooth serviceberry & Amelanchier laevis & \\
\hline porcelain-berry & Ampelopsis brevipedunculata & $\mathbf{X}$ \\
\hline Hercules club & Aralia spinosa & \\
\hline false nettle & Boehmeria cylindrical & \\
\hline trumpet creeper & Campsis radicans & \\
\hline American hornbeam & Carpinus caroliniana & \\
\hline mockernut hickory & Carya alba & \\
\hline sand hickory & Carya pallida & \\
\hline American chestnut & Castanea dentate & \\
\hline Oriental bittersweet & Celastrus orbiculatus & $\mathbf{X}$ \\
\hline sweet pepperbush & Clethra alnifolia & \\
\hline silky dogwood & Cornus amomum & \\
\hline flowering dogwood & Cornus florida & \\
\hline witch grass & Dichanthelium spp & \\
\hline persimmon & Diospyros virginiana & \\
\hline spinulose wood fern & Dryopteris carthusiana & \\
\hline autumn olive & Elaeagnus umbellata & $\mathbf{X}$ \\
\hline strawberry bush & Euonymus americana & \\
\hline
\end{tabular}




\begin{tabular}{|c|c|}
\hline American beech & Fagus grandifolia \\
\hline American holly & Ilex ораса \\
\hline red cedar & Juniperus virginiana \\
\hline mountain laurel & Kalmia latifolia \\
\hline European privet & Ligustrum vulgare \\
\hline spicebush & Lindera benzoin \\
\hline sweet gum & Liquidambar styraciflua \\
\hline tuliptree & Liriodendron tulipifera \\
\hline Japanese honeysuckle & Lonicera japonica \\
\hline sweetbay magnolia & Magnolia virginiana \\
\hline Canada moonseed & Menispermum canadense \\
\hline Japanese stilt grass & Microstegium vimineum \\
\hline northern bayberry & Myrica pensylvanica \\
\hline black gum & Nyssa sylvatica \\
\hline Virginia creeper & Parthenocissus quinquefolia \\
\hline mile-a-minute & Persicaria perfoliata \\
\hline common pokeweed & Phytolacca americana \\
\hline loblolly pine & Pinus taeda \\
\hline Virginia pine & Pinus virginiana \\
\hline large-tooth aspen & Populus grandidentata \\
\hline American plum & Prunus americana \\
\hline wild black cherry & Prunus serotina \\
\hline choke cherry & Prunus virginiana \\
\hline white oak & Quercus alba \\
\hline blackjack oak & Quercus marilandica \\
\hline swamp chestnut oak & Quercus michauxii \\
\hline
\end{tabular}




\begin{tabular}{|c|c|}
\hline water oak & Quercus nigra \\
\hline willow oak & Quercus phellos \\
\hline chestnut oak & Quercus prinus \\
\hline northern red oak & Quercus rubra \\
\hline post oak & Quercus stellata \\
\hline black oak & Quercus velutina \\
\hline swamp azalea & Rhododendron viscosum \\
\hline winged sumac & Rhus copallinum \\
\hline multi-floral rose & Rosa multiflora \\
\hline red rasberry & Rubus idaeus \\
\hline western raspberry & Rubus occidentalis \\
\hline wineberry & Rubus phoenicolasius \\
\hline sassafras & Sassafras albidum \\
\hline green bristle grass & Setaria viridis \\
\hline greenbrier & Smilax spp \\
\hline Johnson grass & Sorghum halepense \\
\hline American bladdernut & Staphylea trifolia \\
\hline coral-berry & Symphoricarpos orbiculatus \\
\hline poison ivy & Toxicodendron radicans \\
\hline eastern hemlock & Tsuga canadensis \\
\hline slippery elm & Ulmus rubra \\
\hline stinging nettle & Urtica dioica \\
\hline highbush blueberry & Vaccinium corymbosum \\
\hline early lowbush blueberry & Vaccinium pallidum \\
\hline maple-leaf viburnum & Viburnum acerfolium \\
\hline arrow-wood & Viburnum dentatum \\
\hline
\end{tabular}


exotic arrow-wood

smooth black-haw

summer grape

Muscadine grape

winter grape
Viburnum dilatatum

$\mathbf{X}$

Viburnum prunifolium

Vitis aestivalis

Vitis rotundifolia

Vitis vulpine 


\section{LITERATURE CITED}

Alldredge, M. W., T. R. Simmons, and K. H. Pollock. 2007. A field evaluation of distance measurement error in auditory avian point count surveys. Journal of Wildlife Management $71: 2759-2766$.

Allombert, S., S. Stockton, and J. Martin. 2005a. A natural experiment on the impact of overabundant deer on forest invertebrates. Conservation Biology 19:1917-1929.

Allombert, S., A. J. Gaston, and J. Martin. 2005b. A natural experiment on the impact of overabundant deer on songbird populations. Biological Conservation 126:1-13.

Anderson, R. C., E. A. Corbett, M. R. Anderson, G. A. Corbett, and T. M. Kelley. 2001. High white-tailed deer density has negative impact on tallgrass prairie forbs. Journal of the Torrey Botanical Society 128: 381-392.

Augustine, D. J., and S. J. McNaughton. 1998. Ungulate effects on the functional species composition of plant communities: herbivore selectivity and plant tolerance. Journal of Wildlife Management 62:1165-1183.

Baiser, B., J. L. Lockwood, D. La Puma, and M. F. J. Aronson. 2007. A perfect storm: two ecosystem engineers interact to degrade deciduous forests of New Jersey. Biological Invasions. Published online 14 March 2008.

http://www.springerlink.com/content/4710418416360254/

Bernatas, S. 2006. Aerial infrared deer survey for Delaware Division of Fish and Wildlife. Vision Air Research. Boise, Idaho, USA. 
Bernatas, S. 2009. White-tailed Deer Population Survey Delaware Division of Fish and Wildlife. Vision Air Research. Boise, Idaho, USA.

Bishop, J. A. and W. L. Meyers. 2005. Associations between avian functional guild response and regional landscape properties for conservation planning. Ecological Indicators 5: 33-48.

Bowman, J. L. 2006. An evaluation of deer management in Delaware. Delaware Division of Fish and Wildlife. Dover, Delaware, USA.

Burghardt, K. T., D. W. Tallamy and W. G. Shriver. 2009. Impact of native plants on bird and butterfly biodiversity in suburban landscapes. Conservation Biology 23: 219-224.

Burnham, K. P. and D. R. Anderson. 2002. Model selection and multimodel inference. Springer-Verlag, New York, New York, USA.

Casey, D. and D. Hein. 1983. Effects of heavy browsing on a bird community in deciduous forest. Journal of Wildlife Management 47: 829-836.

DeCalesta, D. S. 1994. Effect of white-tailed deer on songbirds within forests in Pennsylvania. Journal of Wildlife Management 58:711-718.

Eschtruth, A. K., and J. J. Battles. 2009. Acceleration of exotic plant invasion in a forested ecosystem by a generalist herbivore. Conservation Biology 23:388-399.

Gaston, A. J., S. A. Stockton, and J. L. Smith. 2006. Species-area relationships and the impact of deer-browse in the complex phytogeography of the Haida Gwaii archipelago (Queen Charlotte Islands), British Columbia. Ecoscience 13:511-522. 
Glennon, M. J., and W. F. Porter. 2005. Effects of land use management on biotic integrity: An investigation of bird communities. Biological Conservation 126:499-511.

Hansen, L., and J. Beringer. 1997. Managed hunts to control white-tailed deer populations on urban public areas in Missouri. Wildlife Society Bulletin 25: 484-487.

Harlow, R. F., and R. L. Downing. 1970. Deer browsing and hardwood regeneration in the southern Appalachians. Journal of Forestry 68:298-300.

Hess, G. K., R. L. West, M. V. Barnhill, III, and L. M. Fleming. 2000. Birds of Delaware. University of Pittsburgh, Pennsylvania, USA.

Hines, J. E. 2006. PRESENCE2 - Software to estimate patch occupancy and related parameters. USGS-PWRC. http://www.mbr-pwrc.gov/software/presence.html

Horsley, S. B., and D. A. Marquis. 1983. Interference by weeds and deer with Allegheny hardwood reproduction. Canadian Journal of Forest Research 13:61-69.

MacKenzie, D. I. 2006. Modeling the probability of resource use: the effect of, and dealing with, detecting a species imperfectly. Journal of Wildlife Management 70:367-374.

Martin, A. C., H. S. Zim, and A. L. Nelson. 1951. American wildlife and plants: a guide to wildlife food habits. McGraw-Hill, New York, New York, USA.

McCabe, T. R., and R. E. McCabe. 1997. Recounting whitetails past. Pages 11-26 in W. J. McShea, H. B. Underwood, and J. H. Rappole, editors. The science of overabundance; deer ecology and population management. Smithsonian Institution, Washington, D.C., USA 
McShea, W. J., and J. H. Rappole. 1997. The science and politics of managing deer within a protected area. Wildlife Society Bulletin 25:443-446.

McShea, W. J., and J. H. Rappole. 2000. Managing the abundance and diversity of breeding bird populations through manipulation of deer populations. Conservation Biology 14:11611170.

National Oceanic and Atmospheric Administration (NOAA). 2010. National Weather Service internet services team. Monthly precipitation and temperature for Delaware, USA. <http://www.weather.gov/climate/xmacis.php?wfo=phi>. Accessed 30 Mar 2010.

Nudds, T. D. 1977. Quantifying the vegetative structure of wildlife cover. Wildlife Society Bulletin 5:113-117.

O’Connell, T. J., L. E. Jackson, and R. P. Brooks. 1998. A Bird Community Index of Biotic Integrity for the Mid-Atlantic Highlands. Environmental Monitoring and Assessment 51: 145-156.

Prasad, A. M., L. R. Iverson., S. Matthews., and M. Peters. 2007. A climate change atlas for 134 forest tree species of the eastern United States [database]. <http://www.nrs.fs.fed.us/atlas/tree>. Northern Research Station, USDA Forest Service, Delaware, Ohio, USA.

Ralph, C. J., J. R. Sauer, and S. Droege. 1995. Managing and monitoring birds using point counts: standards and applications. Pages 161-169 in C. J. Ralph, S. Droege, and J. R. 
Sauer, editors. Monitoring bird populations with point counts. U.S. Department of Agriculture, Forest Service, Pacific Southwest Research Station, Albany, California, USA.

Robbins, C. S., D. K. Dawson, and B. A. Dowell. 1989. Habitat area requirements of breeding forest birds of the Middle Atlantic States. Wildlife Monographs 103: 1-34.

Roth, R. R. and R. K. Johnson. 1993. Long-term dynamics of a Wood Thrush population breeding in a forest fragment. The Auk 110: 37-48.

Sauer, J. R., J. E. Hines, and J. Fallon. 2008. The North American Breeding Bird Survey, Results and Analysis 1966 - 2007. Version 5.15.2008. USGS Patuxent Wildlife Research Center, Laurel, Maryland, USA.

Sokal, R. R. and F. J. Rohlf. 1995. Biometry, Third Edition. Freeman and Company, New York, New York, USA.

Thomas, L., S.T. Buckland, E.A. Rexstad, J. L. Laake, S. Strindberg, S. L. Hedley, J. R.B. Bishop, T. A. Marques, and K. P. Burnham. 2010. Distance software: design and analysis of distance sampling surveys for estimating population size. Journal of Applied Ecology 47: 514.

Tilghman, N. G. 1989. Impacts of white-tailed deer on forest regeneration in northwestern Pennsylvania. Journal of Wildlife Management 53:524-532.

United States Geological Survey (USGS). 2007. Strategic Plan for the North American Breeding Bird Survey: 2006-2010. U.S. Geological Survey Circular 1307, Reston, Virginia, USA. 
Waller, D. M., and W. S. Alverson. 1997. The white-tailed deer: a keystone herbivore. Wildlife Society Bulletin 25:217-226.

Williams, B. K., J. D. Nichols, and M. J. Conroy. 2002. Analysis and management of animal populations: modeling, estimation, and decision making. Academic Press. San Diego, California, USA. 